Studia nad Autorytaryzmem i Totalitaryzmem 41, nr 4 Wrocław 2019

DOI: $10.19195 / 2300-7249.41 .4 .2$

WOJCIECH WICHERT

ORCID: 0000-0003-1335-592X

Instytut Pamięci Narodowej, Oddział w Szczecinie

\title{
Ustawa o pełnomocnictwach (Ermächtigungsgesetz) z 23 marca 1933 roku jako katalizator budowy państwa wodzowskiego w Niemczech
}

Pierwszym i priorytetowym celem Adolfa Hitlera po przejęciu władzy w Niemczech 30 stycznia 1933 roku było dążenie do stworzenia totalitarnych zrębów przyszłego państwa wodzowskiego ${ }^{1}$. Wprowadzając systematycznie taki scenariusz w życie, dążył wpierw do ustanowienia dominacji Narodowosocjalistycznej Niemieckiej Partii Robotników (NSDAP) w życiu politycznym i społecznym. Kluczową rolę w tych planach odgrywało ustawodawstwo, czyli ustanowienie takich praw, które zlikwidowałyby liberalny, pluralistyczny porządek normatywny Republiki Weimarskiej. Konstytucja weimarska z 11 sierpnia 1919 roku nie została jednak nigdy formalnie uchylona, jeśli chodzi o sferę prawną przyszłej III Rzeszy. Mimo to należy zaznaczyć, że już za rządów trzech ostatnich kanclerzy republiki (Heinricha Brüninga, Franza von Papena i gen. Kurta von Schleichera) pewne jej przepisy były czasowo zawieszane na mocy kontrowersyjnego art. 48 (ust. 2) Konstytucji ${ }^{2}$. Te panujące po 1930 roku w Niemczech prak-

${ }^{1}$ Szerzej o okolicznościach zdobycia przez Hitlera władzy w Niemczech zob. m.in. E. Fraenkel, Historical handicaps of German parliamentarism, [w:] The Road to Dictatorship: Germany 1918-1933, red. O. Wolff, London 1964, s. 25 n.; M. Broszat, Die Machtergreifung. Der Aufstieg der NSDAP und die Zerstörung der Weimarer Republik, München 1990; E. Carlebach, Hitler war kein Betriebsunfall. Hinter den Kulissen der Weimarer Republik. Die vorprogrammierte Diktatur, Frankfurt am Main 1978; R. Freyh, Stärke und Schwäche der Weimarer Republik, Hannover 1963; W. Horn, Der Marsch zur Machtergreifung. Die NSDAP bis 1933, Königstein 1980; H. Mommsen, Aufstieg und Untergang der Republik von Weimar, Berlin 1998; M. Vogt, Die Weimarer Republik (1918-1933), [w:] Deutsche Geschichte. Von den Anfängen bis zur Wiedervereinigung, red. M. Vogt, Stuttgart 1991, s. 603 n.; J. Pool, S. Pool, Hitlers Wegbereiter zur Macht. Die geheimen deutschen und internationalen Geldquellen, die Hitlers Aufstieg zur Macht ermöglichten, Bern 1979, s. 254 n.

2 Przepis ten stał się w latach 1930-1932 podstawą do wydawania tak zwanych zarządzeń nadzwyczajnych (Notverordnungen), które były niezbędne do ,przywrócenia bezpieczeństwa i po- 
tyki rządowe w dużym stopniu ścieliły nazistom, którzy w żadnych wyborach przed 1933 rokiem nie zdobyli więcej niż 37,8\% głosów, drogę do zwycięstwa. Wskutek permanentnego niemalże kryzysu politycznego, pogłębianego przez depresję ekonomiczną i poczynania samych narodowych socjalistów, zablokowane zostały wówczas drogi tworzenia normalnej większości parlamentarnej, co skutkowało coraz częstszym sięganiem po Notverordnungsrecht, czyli prawo wydawania przez prezydenta Rzeszy, feldmarszałka Paula von Hindenburga dekretów w trybie nadzwyczajnym. Nieuniknionym skutkiem tego procederu było stopniowe przesuwanie się ciężaru władzy na głowę państwa i doradców z jego kamaryli, z których bynajmniej nie tylko jego syn, Oskar von Hindenburg, by użyć popularnego w tamtym czasie dowcipu, „nie był przewidziany przez Konstytucję”. Szerokie możliwości interpretacji art. 48 prowadziły w konsekwencji do dominacji prezydenta nad parlamentem i powstawania „dyktatury prezydenckiej", która poprzedzała narodziny III Rzeszy, czyli totalitarnej dyktatury Hitlera w państwie jednopartyjnym ${ }^{3}$. Droga przyszłego Führera do samowładztwa, której kluczowym momentem było uchwalenie przez Reichstag 23 marca 1933 roku tak zwanej ustawy o pełnomocnictwach (Ermächtigungsgesetz), nadającej gabinetowi prawo wydawania tak zwanych ustaw rządowych, pozostaje w swych poszczególnych etapach ciągle jeszcze klasycznym modelem totalnego opanowania instytucji demokratycznych od wewnątrz, to znaczy - nie w konflikcie z państwem, lecz z jego wydatną pomocą. Była to taktyka łącząca rewolucyjne fakty $\mathrm{z}$ aktami ich prawnego usankcjonowania tak, by w szczegółach bardzo wątpliwa, lecz w całości przekonująca fasada legalności zasłaniała bezprawie tego systemu, który w krótkim czasie przekształcił się w jeden z najbardziej zbrodniczych reżimów w dziejach ${ }^{4}$.

Celem niniejszego artykułu jest przeanalizowanie antecedencji uchwalenia przez niemiecki parlament ustawy o pełnomocnictwach (Ermächtigungsgesetz) oraz politycznych skutków wprowadzenia tego brzemiennego prawa w życie. $\mathrm{W}$ tym celu przedstawione zostaną najważniejsze etapy procesu przejmowania władzy (Machtergreifung) przez Führera i jego ruch po 30 stycznia 1933 roku, a więc przede wszystkim strategia polityczna nowych władców Niemiec, brutalne

rządku publicznego w Rzeszy Niemieckiej, jeżeli porządek i bezpieczeństwo publiczne zostały poważnie zakłócone lub zagrożone". W okresie istnienia Republiki Weimarskiej art. 48 stanowił uzasadnienie prawne dla około 250 aktów normatywnych, wymierzonych we wszelkie działania wywrotowe - antyrepublikańskie i antydemokratyczne. Zob. W. Wichert, Krótki żywot Republiki Weimarskiej, czyli garść uwag na temat przyczyn upadku pierwszej demokracji niemieckiej, cz. 1, https://historia.org.pl/2018/07/20/krotki-zywot-republiki-weimarskiej-czyli-garsc-uwag-na-tematprzyczyn-upadku-pierwszej-demokracji-niemieckiej-cz-1/ (dostęp: 20.12.2018); H. Boldt, Article 48 of the Weimar Constitution, its historical and political implications, [w:] German Democracy Democracy and the Triumph of Hitler: Essays in Recent German History, red. A. Nicholls, E. Matthias, London 1971, s. 85 n.; T. Kotłowski, Historia Republiki Weimarskiej, Poznań 2004, s. 27 n.

${ }^{3}$ W. Wichert, op. cit.

4 J.C. Fest, Oblicze Trzeciej Rzeszy, przeł. E. Werfel, Warszawa 1970, s. 73-74, 80. 
działania w kierunku likwidacji opozycji politycznej, terror policyjny i orgie przemocy bojówek hitlerowskich, erozja praw oraz wolności obywatelskich, budowa zrębów państwa stanu wyjątkowego, a także postawa niemieckich elit, szczególnie konserwatywnych koalicjantów Hitlera, wobec rodzącego się bezprawia i procesu zawłaszczania instytucji publicznych przez nazistów w pierwszych miesiącach ich rządów. Wreszcie poruszony został również problem następstw obowiązywania Ermächtigungsgesetz dla praktyki ustrojowej kształtującej się dyktatury monopartyjnej i absolutyzacji pozycji Hitlera w Niemczech. Tekst oparto głównie na historiografii polskiej, niemieckiej oraz anglosaskiej powstałej po 1945 roku, dotyczącej wewnętrznych dziejów III Rzeszy, zwłaszcza jej systemu prawnego i politycznego.

Hitler wspiął się na urząd kanclerza bez formalnego pogwałcenia konstytucji oraz przy wsparciu konserwatywnych elit oraz armii (Reichswehry), które to podmioty chciały „wynająć” go do „czarnej roboty”, to jest do zniszczenia resztek demokracji, zaprowadzenia porządku w kraju oraz wprowadzenia systemu quasi-autorytarnego ${ }^{5}$. Jak wspomniano, celem Hitlera, już jako przedstawiciela aparatu rządzącego i największej partii w Niemczech, było skupienie w swoich rękach pełni władzy państwowej, co pozwoliłoby mu umiejętnie wyzwolić się spod wpływów swoich politycznych ,zleceniodawców”. Aby tego dokonać, musiał umocnić swoje rządy jeszcze przed śmiercią sędziwego prezydenta Hindenburga. Na razie jednak był tylko kanclerzem w systemie ustrojowym republiki, a dokładniej w koalicyjnym gabinecie ,narodowej koncentracji”, z przewaga konserwatystów z Niemieckiej Narodowej Partii Ludowej (DNVP), na czele z magnatem prasowym Alfredem Hugenbergiem jako szefem resortu gospodarki, rolnictwa oraz wyżywienia.

Oprócz Hitlera w nowym rządzie do NSDAP należał tylko minister spraw wewnętrznych Wilhelm Frick i minister bez teki Hermann Göring. Hitler nie miał więc wówczas wielkiego pola manewru; był skazany na współpracę z doświadczonymi i pewnymi siebie przedstawicielami weimarskiego establishmentu pod patronatem prezydenta i Reichswehry z gen. Wernerem von Blombergiem jako ministrem obrony. Wicekanclerzem i komisarzem Rzeszy ds. Prus został bezpartyjny Franz von Papen, którego zakulisowe rozgrywki w istotny sposób przyczyniły się do powstania nowego gabinetu. Hitler, pomny druzgocącej klęski puczu monachijskiego z listopada 1923 roku, wiedział ponadto, że musi kontynuować

${ }^{5}$ Szerzej zob. R.J. Evans, Trzecia Rzesza u władzy, przeł. M. Grzywa, Oświęcim 2016, s. 17; J.J. Węc, Stanowisko Reichswehry wobec SA w okresie przejmowania władzy w Niemczech przez narodowych socjalistów (1933-1934), „Przegląd Zachodni” 1989, nr 5-6, s. 329 n.; M. Broszat, op. cit., s. 156 n.; K.D. Bracher, W. Sauer, G. Schulz, Die nationalsozialistische Machtergreifung. Studien zur Errichtung des totalitären Herschaftssystem in Deutschland 1933/34, Köln-Opladen 1962, s. 31 n.; W. Horn, op. cit., s. 329 n.; I. Kershaw, Hitler, t. 1. 1889-1936. Hybris, przeł. P. Bandel, Poznań 2010, s. 368.

${ }^{6}$ Zob. F. Ryszka, Państwo stanu wyjątkowego. Rzecz o systemie państwa i prawa w Trzeciej Rzeszy, Wrocław 1985, s. 204 n. 
ustrojowe przekształcenia państwa zgodnie z założeniami „legalnej rewolucji”, opartej na partycypacji jego partii w demokratycznej grze wyborczej. Praktyka prawna narodowych socjalistów w pierwszej fazie po triumfie z 30 stycznia 1933 roku opierała się więc na utrwalaniu przez nich władzy przez ustawy i „poza ustawami"7. Hasło tego etapu Machtergreifung sformułował przyszły minister propagandy Joseph Geobbels - „Władzę zdobywa się przy pomocy władzy”8.

W kontekście politycznych planów konserwatystów warto odnotować, że koalicjanci jeszcze w okresie negocjacji nad sposobem funkcjonowania i składem nowego rządu ${ }^{9}$ uzgodnili najważniejsze wytyczne dotyczące wzmocnienia pozycji egzekutywy. Niemniej po Machtergreifung kwestia ta nie zajmowała wiele miejsca na kolejnych posiedzeniach rządu. Zastanawiano się tylko, w jaki sposób można uzyskać wymaganą większość w parlamencie, aby przeforsować omawiane rozwiązania. Doraźne komplikacje budził także problem współudziału prezydenta w procesie ustawodawczym, co szczególnie podnosił minister Hugenberg. Ostatecznie uznano, że Hindenburg nie będzie wymagał swojego aktywnego uczestnictwa w podejmowaniu decyzji przez rząd ${ }^{10}$. Wicekanclerz Papen wystąpił natomiast z dezyderatem, żeby opracować zupełnie nową konstytucję, która akcentowałaby autorytarny kurs władzy. Hitler początkowo przychylił się do tej propozycji, podkreślając, że nowa ustawa zasadnicza mogłaby zostać uchwalona przez Zgromadzenie Narodowe. Wobec braku ogólnej zgody na umieszczenie tych przepisów w programie gabinetu zamiar ten ostatecznie upadł ${ }^{11}$.

Początkowo w celu wzmocnienia pozycji narodowych socjalistów w rządzie Hitler polecił swoim pretorianom z SS (Schutzstaffel) i SA (Sturmabteilung), żeby wydatnie zintensyfikowali przemoc na ulicach, to znaczy — bardziej ,przyłożyli się" do brutalnego pacyfikowania marksistowskich przeciwników z KPD (Komunistyczna Partia Niemiec) i powiązanej z SPD (Socjaldemokratyczna Partia Niemiec) republikańskiej organizacji paramilitarnej Reichsbanner Schwarz-Rot-Gold, a także do rozbijania ich zebrań partyjnych. Przekonał von Papena, żeby mianował Göringa pruskim ministrem spraw wewnętrznych i szefem tamtejszych sił porządkowych. W tym charakterze Göring niezwłocznie zwerbował SA do roli policji pomocniczej. Jego brunatne koszule zabrały się do szaleńczego działania,

${ }^{7}$ H. Hattenhauer, Die geistesgeschichtlichen Grundlagen des deutschen Rechts, Heidelberg 1983, s. 317.

8 J.C. Fest, op. cit., s. 75.

${ }^{9}$ Szerzej o tej kwestii zob. K.D. Bracher, Die Auflösung der Weimarer Republik. Eine Studie zum Problem des Machtverfalls in der Demokratie, Stuttgart-Düsseldorf 1955, s. 686 n.; H. Brüdigam, Das Jahr 1933. Terrorismus an der Macht. Eine Dokumentation über die Errichtung der faschistischen Diktatur, Frankfurt am Main 1978, s. 11 n.; J. Pajewski, W jakich okolicznościach zostat Hitler kanclerzem Rzeszy, „Przegląd Zachodni” 1949, nr 9-10, s. 326 n.

${ }^{10}$ Zob. K.H. Minuth, Akten der Reichskanzlei. Regierung Hitlers 1933-1938, t. 1. 30 Januar bis 31 August 1933, Boppard am Rhein 1983, s. 216 n.

${ }^{11}$ E. Jäckel, Panowanie Hitlera. Spetnienie światopoglądu, przeł. A. Karszniewicz-Mazur, Wrocław 1989, s. 45. 
demolując biura związków zawodowych, bijąc komunistów i rozpędzając wiece socjaldemokratów. Na mocy specjalnego dekretu z 6 lutego 1933 roku posiadł on de facto pełnię władzy w tym kraju związkowym ${ }^{12}$. Jeszcze wcześniej, bo 2 lutego, na mocy decyzji Göringa zakazano wieców KPD w Prusach ${ }^{13}$. Z kolei 17 lutego wydany został nakaz strzelania (Schiessbefehl ${ }^{14}$ ) dla policji, której celem miała być brutalna eliminacja każdego przeciwnika nowych porządków. Działania te, podejmowane rzekomo w majestacie prawa, znamionowały koniec neutralności państwa jako instytucji i zaangażowanie jego aparatu do bezwzględnej rozgrywki politycznej, która rozpoczęła się zaraz po mianowaniu Hitlera kanclerzem Rzeszy. W rzeczywistości 30 stycznia 1933 roku wyznaczył początek przejmowania pełnej władzy przez narodowych socjalistów, a nie świt konserwatywnej kontrrewolucji ${ }^{15}$.

Zaledwie dzień po zaprzysiężeniu ministrów gabinetu ,narodowej koncentracji” rozwiązano parlament i zarządzono na 5 marca 1933 roku nowe wybory. Hitler zamierzał w ten sposób podporządkować sobie nowo wybrany Reichstag oraz zminimalizować rolę bloku deutschnationale w rządzie, pozbywając się tym samym elementów opozycyjnych, które hamowały jego dążenia do przeprowadzenia „narodowej rewolucji”. Ten zręczny zabieg Hitlera szedł w kierunku pochwycenia nieograniczonej kontroli nad państwem. Należy zaznaczyć, że zadanie to zostało znacznie ułatwione przez Reichswehrę, która pod kierownictwem ministra von Blomberga coraz bardziej sprzyjała nazistom, licząc na realizację szumnie zapowiadanych haseł o remilitaryzacji. Wsparcie nadeszło również ze strony biurokracji państwowej, aparatu wymiaru sprawiedliwości oraz regionalnych struktur administracyjnych. Hindenburg, zwiedziony uspokajającymi gestami oraz zapewnieniami Hitlera dotyczącymi polityki wewnętrznej ${ }^{16}$, przyzwalał na stosowanie ustawodawstwa wyjątkowego (zgodnie z art. 48 Konstytucji). W konsekwencji błędnych kalkulacji prezydenta narodowi socjaliści systematycznie zyskiwali dominujący wpływ na życie publiczne w Niemczech ${ }^{17}$. Już w lutym

12 Niemniej dopiero 20 kwietnia 1933 roku Hitler formalnie powierzył Göringowi funkcję premiera Prus. Zob. J. Wąsicki, Polityka hitlerowska w zakresie administracji państwa, „Studia nad Faszyzmem i Zbrodniami Hitlerowskimi" 11, 1987, s. 135.

13 Aby wzmocnić siły policyjne w Prusach, 26 kwietnia 1933 roku Göring utworzył Tajną Policję Państwową (Geheime Staatspolizei), która zyskała później złą sławę, brutalnie tłumiąc wszelkie przejawy oporu w Rzeszy, a później w krajach okupowanych. Szerzej zob. R. Butler, Gestapo, przeł. M. Antosiewicz, Warszawa 2007, s. 22 n.; E. Crankshaw, Gestapo, przeł. J. Dewitz, Warszawa 1995, s. 9 n.; J. Witkowski, Gestapo. Anatomia systemu, Warszawa 2005, s. 5 n.

${ }^{14}$ Zob. Runderlass des Reichskommissars für das Preussische Ministerium des Innern Hermann Göring an alle Polizeibehörden über die „,Förderung der nationalen Bewegung” (sog. Schiesserlass), [w:] Deutsche Geschichte 1933-1945. Dokumente zur Innen- und Aussenpolitik, red. W. Michalka, Frankfurt am Main 2002, s. 18-19.

15 R.J. Evans, op. cit., s. 17.

16 Zob. szerzej K.H. Minuth, op. cit., s. 29 n.

${ }^{17}$ K.D. Bracher, The technique of the national socialist seizure of power, [w:] The Road to Dictatorship..., s. 119. 
1933 roku ukazały się trzy nadzwyczajne rozporządzenia sygnowane przez prezydenta, które zapowiadały nieuchronny koniec republiki. Najpierw 4 lutego wyszło Rozporządzenie Prezydenta Rzeszy o ochronie narodu niemieckiego (Die Verordnung des Reichspräsidenten zum Schutze des Deutschen Volkes ${ }^{18}$ ), które przyznawało rządowi prawo do zakazywania politycznych manifestacji, agitacji oraz wydawania prasy przez opozycyjne partie. Był to w zasadzie pierwszy krok do delegalizacji konkurencyjnych ugrupowań. Kolejne rozporządzenie dotyczyło rozwiązania pruskiego parlamentu, z zaznaczeniem, że nadchodzące wybory miały się tam pokrywać z głosowaniem ogólnokrajowym. Zniszczeniu lewicy niemieckiej, zwłaszcza komunistów, miał z kolei posłużyć dekret z 21 lutego, mówiący o zaostrzeniu aktów represji wobec „wrogów państwa”. Fala terroru i aresztowań ogarnęła całe państwo. Oprócz socjaldemokratów i komunistów represje spotykały Żydów, duchownych katolickich, a także polityków i dziennikarzy, którzy ośmielali się jeszcze myśleć inaczej, niż chciała tego władza. Poczucie zagrożenia miało stać się odtąd nieodłącznym elementem życia obywateli niemieckich. Walka przedwyborcza oznaczała w tamtym czasie starcia przypominające wręcz wojnę domową, gdyż NSDAP chciała wykorzystać wszystkie możliwości, aby umocnić zdobyte pozycje. Prowadziło to nieuchronnie do konfliktu ze wszystkimi partiami, z ustrojem demokratycznym, z lewicą komunistyczną, ale też z prawicową DNVP, której baza parlamentarna była wówczas słaba $(10,8 \%$ głosów w wyborach z 6 listopada 1932 roku) ${ }^{19}$.

Należy jeszcze podkreślić w kontekście taktyki politycznej Hitlera w pierwszych miesiącach po Machtergreifung, że nieprzejrzystość procesu umacniania władzy przez nazistów, realizowanego głównie za wygodnym sztafażem świadomie utrzymywanych dawnych form instytucjonalnych, stanowiła jego decydującą cechę, brzemienną w następstwa. Hitler nie tylko przejął i udoskonalił elementy wypróbowanej faszystowskiej techniki zamachu stanu, lecz także kontynuował własną strategię z tak zwanego okresu walki (Kampfzeit), to jest z czasów sprzed 1933 roku $^{20}$. Zgodnie z tą taktyką nie ingerowano na razie w pewne dziedziny życia publicznego - chociażby sądownictwu cywilnemu pozostawiono początkowo daleko idącą niezależność. Obszary te były swoistymi wyspami praworządności pośród fal głębokiego przewrotu, który ogarniał wszelkie stosunki społeczne, uspokajającymi rezerwatami tradycyjnych wyobrażeń ,apolitycznych” Niemców o ładzie i porządku. Część czynników i środowisk, powołanych do stania na

18 Reichsgesetzblatt I 1933, s. 35.

19 W. Benz, Historia Trzeciej Rzeszy, przeł. R. Kazior, Warszawa 2006, s. 19. Nawet najbardziej zachowawcze, na wpół oficjalne ustalenia mówią łącznie o ponad 100 tysiącach politycznych aresztowań w Niemczech w 1933 roku, a także o niemal 600 przypadkach śmierci przetrzymywanych. Była to więc fala brutalnej przemocy i morderstw na oszałamiającą wręcz skalę, nienotowaną w tym kraju od pierwszych dni Republiki Weimarskiej. Zob. R.J. Evans, Nadejście Trzeciej Rzeszy, przeł. M. Grzywa, Oświęcim 2015, s. 354.

20 Zob. H. Schreckenberg, Ideologie und Alltag im Dritten Reich, Frankfurt am Main 2003, s. $32 \mathrm{n}$. 
straży praworządności, nie bez troski przyglądała się polityce prowadzącej do budowy jawnej dyktatury. Balansując na krawędzi legalności, nie zadowalała się wyświechtaną formułą „gdzie drwa rąbią, tam drzazgi lecą”, reagowała jednak prawie powszechnie w sposób, który tylko sprzyjał dążeniom do przejęcia władzy przez nazizm. Wielu Niemców liczyło na to, że poprzez gotowość do współpracy przeszkodzą „najgorszym wybrykom”, nie dopuszczą do jawnego przekroczenia granic prawa, nałożą cugle rewolucyjnej swawoli szczególnie brunatnych szturmówek, którymi Hitler nie przestawał szantażować, trzymając je w rezerwie jako potencjalną groźbę ${ }^{21}$. Duża część obywateli nie opierała się jednak szczególnie nowemu reżimowi. Wręcz przeciwnie, powszechnym zjawiskiem było wstępowanie wówczas w szeregi NSDAP ${ }^{22}$. Wierzono przy tym, że dojście Hitlera do władzy stanowi początek nowych, lepszych czasów dla kraju. Głośno wychwalano dążenie władzy do ponownego zaprowadzenia porządku i wzmocnienia poczucia bezpieczeństwa publicznego. Niekiedy usprawiedliwiano nawet terror nazistów, mówiąc, że jest to teraz konieczne, aby zbudować silne podstawy rządzenia, które przełożą się w przyszłości na pomyślność obywateli. Obojętnie lub nawet $\mathrm{z}$ nieskrywaną radością obserwowano rozwój wypadków ${ }^{23}$.

Mistrzowska taktyka maskowania się, pod której osłoną działała dyktatura, sprzyjała tym złudzeniom i przyczyniła się do tego, że stan urzędniczy, armia, lecz także partie polityczne i związki zawodowe, przede wszystkim zaś prawnicy, wśród których silne były zarówno nacjonalistyczne uprzedzenia, jak i czołobitny lojalizm wobec wszelkich praw, poparły dążenia do totalnej władzy, a przecież, przynajmniej po części, jej właśnie starały się zapobiec. Błyskawiczne tempo wypadków, które zadawały pozycjom przeciwników jeden cios za drugim, tak że nieznaczne, podzielone i zniechęcone siły, skłonne do ewentualnego oporu nie miały możliwości skupienia się i sformowania szyków na nowo ${ }^{24}$. W tym kontekście należy wspomnieć, że porażką zakończyła się próba utworzenia frontu ludowego, złożonego z niemieckich komunistów i socjaldemokratów, który najprawdopodobniej mógł jeszcze zapobiec wzrostowi dominacji NSDAP. Pomimo porzucenia na moment teorii socjalfaszyzmu komuniści obwiniali pośrednio SPD za triumf narodowych socjalistów, która to partia była oskarżana między

${ }^{21}$ J.C. Fest, op. cit., s. 80-81.

22 Niemcy, którzy masowo wstępowali po Machtergreifung do NSDAP, byli nazywani sardonicznie „marcowymi fiołkami” lub „ofiarami marca” (Märzgefallenen), ponieważ zapisali się do ugrupowania po wyborach z 5 marca 1933 roku. W ciągu pierwszych dwóch lat rządów Hitlera do partii wstąpiło około 1,6 miliona nowych członków, z czego dwie trzecie stanowili zwykli oportuniści. Rekrutację nowych członków wstrzymano 1 maja 1933 roku, jednak mimo to niektórzy chętni nadal znajdowali sposób, aby dostać się do NSDAP. Po zniesieniu tego ograniczenia liczba partyjnych towarzyszy (Parteigenosse, Pg.) wzrosła do 8,5 miliona. Zob. W. Benz, op. cit., s. 29; R. Grunberger, Historia społeczna III Rzeszy, przeł. W. Kalinowski, t. 1, Warszawa 1987, s. 96 n.; S.G. Payne, A History of Fascism 1914-1945, Madison 1995, s. 181.

23 Zob. L. Rees, Naziści. Ostrzeżenie historii, przeł. S. Kędzierski, Warszawa 1998, s. 50 n.

24 J.C. Fest, op. cit., s. 81. 
innymi o fiasko zorganizowania wspólnej akcji strajkowej Komunistycznej Partii Niemiec i Komisji Generalnej Związków Zawodowych (Allgemeiner Deutscher Gewerkschaftsbund) na koniec stycznia 1933 roku. Podkreślali również, że socjaldemokracja „zdemobilizowała” masy, gdyż wskutek jej działań burżuazja bez większego oporu przekazała władzę Hitlerowi i narodowym socjalistom, którzy atakowali klasę robotniczą prowokacjami, krwawym terrorem i „politycznym gangsterstwem" 25 . Według błędnych kalkulacji komunistów przejęcie władzy przez rząd Hitlera było ostatnim tchnieniem dogorywającego systemu kapitalistycznego, który szybko upadnie, ścieląc drogę rewolucji proletariatu. Z kolei socjaldemokraci nie chcieli współpracować z partią sterowaną z Moskwy, której krętactw i braku skrupułów słusznie się obawiali. Ich bojówki paramilitarne twardo walczyły z nazistami na ulicach, lecz nie miałyby szans z armią popierającą gabinet Hitlera przez cały 1933 rok, a ponadto liczebnie zdecydowanie ustępowały szturmowcom (w lutym tegoż roku było już ponad 750 tysięcy esamanów). W tej konstelacji politycznej socjaldemokraci chcieli uniknąć bratobójczego rozlewu krwi i pozostali wierni swej tradycji przestrzegania prawa ${ }^{26}$.

Narodowym socjalistom 28 lutego 1933 roku dodatkowo pomógł ślepy los. Działający samodzielnie holenderski anarchosyndykalista, Marinus van der Lubbe, podpalił gmach Reichstagu w proteście przeciwko niesprawiedliwości i bezrobociu. Zdarzenie to stanowiło doskonały pretekst do realizacji wcześniejszych planów Hitlera o pochwyceniu całkowitej władzy i likwidacji resztek państwa prawnego (Rechtsstaat) w Niemczech. Hitler i Göring bez problemu przekonali ochoczy gabinet do zmiażdżenia KPD. Już następnego dnia doszło do aresztowań funkcjonariuszy komunistycznych na wielką skalę. Oskarżano ich o próbę przeprowadzenia zamachu stanu, którego początkiem miał być właśnie pożar niemieckiego parlamentu ${ }^{27}$. Cztery tysiące komunistów, w tym dosłownie całe kierownictwo ugrupowania, natychmiast aresztowano, bito, torturowano i umieszczano w nowo utworzonych obozach koncentracyjnych ${ }^{28}$. Na fali tych wydarzeń już 28 lutego ukazało się Rozporządzenie Prezydenta Rzeszy o ochronie narodu i państwa (Die Verordnung

25 Zob. G. v. Roon, Widerstand im Dritten Reich. Ein Überblick, München 1990, s. 53; A.I. Sobolew et al., Międzynarodówka komunistyczna 1919-1943. Zarys historyczny, przeł. M. Wolska, Warszawa 1974, s. 149.

${ }^{26}$ R.J. Evans, Trzecia Rzesza..., s. 18.

27 Szerzej na temat okoliczności pożaru Reichstagu i następującego po nim procesu rzekomych winowajców zob. H. Brüdigam, op. cit., s. 80 n.; T. Bernaś, F. Bernaś, Podpalacze Reichstagu, Szczecin 1989, s. 41 n.

${ }^{28}$ R.J. Evans, Trzecia Rzesza..., s. 17. Minister Frick 9 marca 1933 roku ogłosił utworzenie obozów koncentracyjnych, w których zamykano opornych w stosunku do nowej władzy. Pierwszym tego rodzaju miejscem odosobnienia był obóz w Dachau niedaleko Monachium, stanowiący pierwowzór dla pozostałych tego typu placówek w Niemczech. Zob. T. Musioł, Dachau 19331945, Katowice 1971, s. 31 n.; B. Behning, Z badań nad struktura grup w obozie koncentracyjnym Dachau (1933-1938), Opole 1988, s. 19 n. 
des Reichspräsidenten zum Schutz von Volk und Staat ${ }^{29}$, inaczej: „ustawa o pożarze Reichstagu"30), które miało uchronić kraj przed „zamachami komunistycznymi”. „Chwilowo" zawieszono więc ustępy Konstytucji gwarantujące wolność osobistą i polityczną obywateli ${ }^{31}$. Zezwolono też na ograniczenia wolności osobistej, wolności prasy, prawa do wyrażania swoich poglądów i myśli oraz swobody zrzeszania się (zakaz zgromadzeń i tworzenia związków). W ramach tych przepisów możliwe stało się również naruszanie tajemnicy korespondencji, przeprowadzanie rewizji domowych, a nawet konfiskaty własności. Wprowadzono ponadto odpowiedzialność zbiorową i najsurowsze represje w wypadku wystąpienia przeciw władzy (kara śmierci) ${ }^{32}$; umożliwiano również stosowanie tak zwanego aresztu prewencyjnego (Schutzhaft ${ }^{33}$ ), zezwalającego na pozbawienie wolności obywatela bez konieczności przedstawienia nakazu sądowego. Oprócz regulacji natury karnej ustalono także, że w razie konieczności rząd Rzeszy może przejąć uprawnienia krajów związkowych w celu przywrócenia tam porządku, ładu i bezpieczeństwa publicznego. Działalność opozycyjnych partii została zatem poważnie utrudniona, a wielu urzędników, głównie socjaldemokratów i adherentów republiki, zwolniono z pracy. Nazwano to „oczyszczaniem administracji państwowej” i ,zabezpieczeniem interesów narodowych".

Samotny czyn van der Lubbego został przedstawiony przez Goebbelsa jako wynik komunistycznego spisku mającego na celu rozpętanie zbrojnego powstania. Przekonało to skutecznie wielu wyborców z klasy średniej, że dekret jest słuszny. $\mathrm{W}$ istocie był to początek dyktatury i demontażu państwa prawa ${ }^{34}$. Wprowadzanie w życie stanu wyjątkowego nie leżało w kompetencjach prezydenta, lecz kanclerza i ministra spraw wewnętrznych, czyli polityków NSDAP. Sojusznicy Hitlera z DNVP i von Papen, który jako człowiek zaufania prezydenta widział się w roli wpływowego strażnika status quo, nie zdawali sobie sprawy, jak bardzo związali

${ }^{29}$ Zob. Rozporzadzenie Prezydenta Rzeszy o ochronie narodu i państwa z 28 II 1933 r., [w:] Historia ustroju państwa w tekstach źródtowych, red. B. Lesiński, J. Walachowicz, Warszawa-Poznań 1992, s. 169.

${ }^{30}$ Z języka niemieckiego: Die Reichstagsbrand-Verordnung. Zob. M. Broszat, Der Staat Hitlers. Grundlegung und Entwicklung seiner inneren Verfassung, München 1992, s. 100 n. Dekret ten został tego samego dnia uzupełniony o prezydenckie rozporządzenie ,przeciwko zdradzie narodu niemieckiego i przygotowaniu zdrady głównej" (Die Verordnung des Reichspräsidenten gegen Verrat am Deutschen Volke und hochverräterische Umtriebe). Zob. Reichsgesetzblatt I 1933, s. 85.

${ }^{31}$ K. Jonca, National socialist law in the Third Reich, „Studia nad Faszyzmem i Zbrodniami Hitlerowskimi" 5, 1980, s. 30.

${ }^{32}$ K. Chojnicka, W. Kozub-Ciembroniewicz, Doktryny polityczne XIX i XX wieku, Kraków 2000, s. 363.

33 Zob. M. Broszat, Nationalsozialistische Konzentrationslager 1933-1945, [w:] Die SS das Herrschaftsinstrument. Befehl und Gehorsam, red. H. Buchheim, t. 2, München 1989, s. 13-15; K. Jonca, Areszt ochronny - pozasądowym środkiem walki z opozycja antyhitlerowska na Ślasku Opolskim (1933-1934), „Studia Śląskie” 12, 1967, s. 105 n.

34 R.J. Evans, Trzecia Rzesza..., s. 17. 
sobie ręce, godząc się na takie rozwiązanie. Błędnie utrzymywali zrazu, że to kolejny dekret prezydencki, podobny do aktów wydawanych od jesieni 1930 roku $^{35}$.

Realizacja przywołanych zarządzeń oznaczała w praktyce przeprowadzenie zamachu stanu przez nazistów, co jawnie kłóciło się z głoszoną nadal oficjalnie przez Hitlera taktyką „legalnej rewolucji”. Decyzja Hindenburga, żeby to przywódca NSDAP, a nie Reichswehra przywrócił porządek w państwie, miała bardzo doniosłe reperkusje, które zdecydowały ostatecznie o przyszłości konserwatystów. Nie dostrzegali oni faktu, że podjęte przez narodowych socjalistów działania wymierzone w lewicę obrócą się niedługo przeciwko nim samym ${ }^{36}$. Mimo najrozmaitszych prób zdławienia lewicowej opozycji, eliminacji komunistów, zastraszenia $\mathrm{SPD}^{37}$ i katolickiego Centrum wyniki wyborów z 5 marca nie mogły napawać radością Hitlera i jego świty. Uruchomienie ogromnej machiny propagandowej i agitacyjnej nie przyczyniło się do spektakularnego sukcesu NSDAP. Zdobyła ona bowiem tylko 43,9\% głosów (17 milionów), co dawało jej 288 miejsc w parlamencie. Koalicjanci Hitlera, startujący wówczas jako Czarno-Biało-Czerwony Front Walki ${ }^{38}$ (Kampffront), uzyskali jeszcze mniej głosów, bo zaledwie 8\% (52 miejsca); z ramienia SPD do Reichstagu weszło 120 deputowanych, z KPD -81 , natomiast $\mathrm{z}$ partii katolickich $-92^{39}$. Pomimo rozczarowania osiągniętymi wynikami i nieosiągnięcia większości dwóch trzecich koniecznej do zmiany konstytucji naziści ogłosili swój triumf, który według nich miał charakter rewolucyjny. Ich lider, a zarazem szef zwycięskiego ugrupowania, nie zamierzał dłużej liczyć się ze zdaniem swoich koalicjantów. W takim zamiarze dodatkowo utwierdzała go nowa konstelacja polityczna w Reichstagu. Komuniści bowiem, choć uzyskali w głosowaniu blisko pięciomilionowe poparcie, nie mogli należycie wypełnić mandatu ofiarowanego im przez naród. Większość deputowanych KPD przebywała wówczas $w$ areszcie $w$ rezultacie masowych zatrzymań przedstawicieli tej partii po pamiętnym pożarze z 28 lutego. Stała się w efekcie rzecz niesłychana — przynależne im miejsca w parlamencie ogólnokrajowym i pruskim pozostawały puste ${ }^{40}$. Ten zręczny zabieg Hitlera pozwolił narodowym socjalistom na uzyskanie niekwestionowanej supremacji w obu izbach. Nie musieli oni tym samym starać się o podtrzymanie sojuszu z DNVP ${ }^{41}$. Hitler nie krył,

35 W. Benz, op. cit., s. 19, 21.

36 E. Fraenkel, Państwo prerogatywne, [w:] Faszyzmy europejskie (1922-1945) w oczach wspótczesnych i historyków, red. J.W. Borejsza, przeł. A. Kreisberg et al., Warszawa 1979, s. 241.

${ }^{37}$ Szerzej zob. A. Czubiński, Lewica niemiecka $w$ walce z dyktatura hitlerowska, Warszawa 1973, s. 44 n.

38 Zob. M. Maciejewski, Ustanowienie rządów hitlerowskich $w$ ocenach niemieckich konserwatystów (1933-1934), „Przegląd Zachodni” 1992, nr 4, s. 23 n.

39 Zob. J.W. Falter, Hitlers Wähler, München 1991, s. 38 n.

40 Zob. K.H. Minuth, op. cit., s. 212 n.; Pressenmeldung vom 12. März über die Nichtzulassung der gewählten Abgeordneten der KPD zum Reichstag und zum Preussischen Landtag, [w:] K. Scheel, 1933. Der Tag von Potsdam, Berlin 1996, s. 96.

${ }^{41}$ Sukcesowi wyborczemu NSDAP towarzyszyły wówczas liczne zmiany w składzie rządów krajowych, gdzie wszystkie kluczowe urzędy objęli naziści, a szefem każdego krajowego gabinetu z reguły zostawał miejscowy gauleiter partii. Zręcznie ominięto zawiły sposób ukonstytuowania

Studia nad Autorytaryzmem i Totalitaryzmem 41, nr 4, 2019

(C) for this edition by CNS 
że nie chce już zależeć od większości parlamentarnej i koalicyjnego wsparcia konserwatystów - pragnął uprawnień dyktatora, czego domagał się zresztą od lat w niezliczonych przemówieniach ${ }^{42}$.

Od czasu wyborów do Reichstagu 5 marca 1933 roku — ostatnich o charakterze wielopartyjnym po zdobyciu władzy przez nazistów — rozpoczął się kolejny etap ,ujednolicania” (Gleichschaltung), zmierzający do przekazania rządowi Hitlera specjalnych pełnomocnictw ustawodawczych, które miały doprowadzić do podważenia decydującej roli konstytucji w systemie prawnym oraz wprowadzenia szczególnego sposobu wykonywania ustaw ${ }^{43}$. Miał to być ostatni krok legislacyjny, który zabezpieczyłby panowanie nowego kanclerza i zarazem ugruntował przewodnią rolę NSDAP w kierowaniu państwem w przyszłości. Do tego celu miał posłużyć wybrany niedawno parlament. Jak na ironię właśnie w ten sposób zamierzano ostatecznie rozprawić się z tym organem władzy, pozbawiając de facto Reichstag jakiegokolwiek znaczenia politycznego w Niemczech. Mimo że koniec Republiki Weimarskiej został w rzeczywistości przypieczętowany wraz z przyjęciem „ustawy o pożarze Reichstagu” z 28 lutego 1933 roku, Hitler nadal zamierzał stwarzać pozory, że działa w sposób legalny. Miało to bowiem ważne znaczenie z punktu widzenia zarówno psychologicznego, jak i prawniczego, aby przejęcie absolutnej władzy przez nazistów odbyło się na zasadzie formalnej legitymizacji. W kalkulacjach kanclerza istotną rolę odgrywała też reakcja zagranicy na poczynania nowego rządu. Wszystkie decyzje Hitlera musiały zatem, przynajmniej na początku, uwzględniać podstawowe normy prawne, włącznie z Konstytucją. Chodziło o to, aby wprowadzenie dyktatury zostało zabezpieczone przed wszelkimi wrogimi reakcjami społeczności europejskiej, która miała zostać przekonana, że przemiany ustrojowe, jakie odbywają się w Niemczech, noszą znamiona ciągłości. Z tego też względu starano się umiejętnie maskować wszelkie bezwzględne przejawy terroru i prześladowania oponentów polityczno-ideologicznych.

Czar quasi-legalności prysł jednak bardzo szybko, zwłaszcza po ograniczeniu roli opozycyjnych sił politycznych w nowym Reichstagu, którego posiedzenie zwołano tymczasem na 23 marca do sąsiedniej opery Krolla ${ }^{44}$. Parlament

się tych rządów poprzez powołanie komisarzy Rzeszy, którymi zostawali zaufani Hitlera, tacy jak gen. Ritter von Epp w Monachium czy Manfred Freiherr von Killinger w Saksonii. Podobnie było w Hamburgu, Hesji, Lubece, Bremie, Wirtembergii i pozostałych landach, gdzie hitlerowcy tworzyli zdominowane przez siebie rządy. Zob. J.C. Fest, Hitler, t. 2. Führer, przeł. W. Jeżewski, Warszawa 1996, s. 42; J. Wąsicki, op. cit., s. 125 n.

42 W. Benz, op. cit., s. 21.

43 Zob. A. Mycielski, Podstawy ustroju Niemiec wspótczesnych, [w:] Pod znakiem swastyki. Polscy prawnicy wobec Trzeciej Rzeszy 1933-1939. Wybór pism, red. M. Maciejewski, M. Marszał, Kraków 2005, s. 124 n.

${ }^{44}$ Warto odnotować, że dwa dni wcześniej, to jest 21 marca, odbyło się też uroczyste otwarcie kadencji nowego parlamentu w Kościele Garnizonowym w Poczdamie, gdzie znajdowały się grobowce pruskich królów: Fryderyka Wilhelma I i jego syna Fryderyka Wielkiego. W ustalony dzien, w rocznicę otwarcia przez Ottona von Bismarcka pierwszego Reichstagu w 1871 roku, odbyła się tam słynna uroczystość znana jako „dzień poczdamski” (Tag von Potsdam). Uścisk dłoni,

Studia nad Autorytaryzmem i Totalitaryzmem 41, nr 4, 2019

(C) for this edition by CNS 
był całkowicie zdominowany przez członków NSDAP (288 miejsc). Narodowi socjaliści mieli widoczną przewagę w izbie po unieważnieniu przez rząd 15 marca mandatów deputowanych KPD, którzy wraz z szefem tego ugrupowania Ernstem Thälmannem przebywali wówczas w tak zwanym areszcie prewencyjnym. Członkowie innych partii opozycyjnych zajmowali w sumie 278 miejsc $^{45}$. Co więcej, dzięki zabiegom Hitlera zamierzano zmienić zasady głosowania w parlamencie. Wprowadzono przepis mówiący o tym, że nieobecnych posłów, którzy nie przedstawili koniecznego usprawiedliwienia, liczono tak, jakby byli obecni na sali ${ }^{46}$. Sprytne posunięcie kanclerza, aby nie dopuścić do obrad komunistów, bardzo się opłaciło. Ograniczenie działalności partii komunistycznej miało również ten skutek, że osłabiało jednocześnie pozycję innej frakcji, a mianowicie SPD, która straciła zresztą część swego poparcia społecznego (około 2\% głosów). Naziści zdyskontowali tym samym ponownie fakt rozłamu środowisk robotniczych w Niemczech. Dla uchwalenia pełnomocnictw gabinetowych potrzebna była konstytucyjna większość dwóch trzecich głosów. Do tego celu Hitler, poza wyeliminowaniem z gry KPD, musiał uzyskać także pomoc partii centrowych. Postawa katolickiej partii Centrum była zatem decydująca i to od niej de facto zależało pomyślne przeforsowanie omawianej ustawy. Aby uzyskać poparcie tego stronnictwa, Hitler rozpoczął szeroko zakrojoną akcję propagandową wśród prominentów i elektoratu tej mieszczańskiej partii, która wcześniej tak stanowczo kontestowała ruch nazistowski w Niemczech, poczynając od szczebla regionalnego ${ }^{47}$.

jaki z tamtej okazji wymienili Hindenburg i Hitler, stał się propagandowym symbolem narodowego pojednania i fraternizacji „starych”, mieszczańsko-konserwatywnych Niemiec, czyli prezydenta, Reichswehry, całej tradycji Hohenzollernów, oraz Niemiec „nowych” spod znaku narodowej rewolucji Hitlera i jego opryszków. W tym samym dniu weszły również w życie trzy zarządzenia prezydenta na mocy art. 48 Konstytucji, a mianowicie o zwalczaniu ,podziemnej działalności przeciw rządowi narodowego odrodzenia”, o ustanowieniu sądów specjalnych, a także o amnestii za „czyny przestępcze popełnione w związku rewolucją narodową" (in Zusammenhang mit der nationalen Erhebung). Akty te sankcjonowały bezwzględne represje wobec opozycji politycznej, zakazywały krytyki rządu oraz zwalniały przedstawicieli władzy z odpowiedzialności karnej za brutalne czyny popełnione w trakcie pierwszego okresu jej funkcjonowania. Zob. K. Scheel, op. cit., s. 39 n.; S. Salmonowicz, Prusy. Dzieje państwa i społeczeństwa, Poznań 1987, s. 566-567; G. Labuda, Dzieje Prus jako zagadnienie historiograficzne, „Przegląd Zachodni” 1995, nr 2, s. 202; R.G. Reuth, Goebbels, przeł. M. Misiorny, Warszawa 1996, s. 198; W. Benz, Herrschaft und Gesellschaft im nationalsozialistischen Staat. Studien zur Struktur- und Mentalitätgeschichte, Frankfurt am Main 1990, s. 13; Verordnung des Reichspräsidenten zur Abwehr heimtückischer Angriffe gegen die Regierung der nationalen Erhebung, vom 21 III 1933, [w:] Der Nationalsozialismus. Dokumente 1933-1945, red. W. Hofer, Frankfurt am Main 1957, s. 55-56; F. Ryszka, op. cit., s. 207.

45 Wraz z głosami koalicyjnego Kampffrontu naziści dysponowali ogółem 341 głosami w Reichstagu. Zob. H.U. Thamer, Verführung und Gewalt. Deutschland 1933-1945, Berlin 1986, s. 272-274.

46 M. Burleigh, Trzecia Rzesza. Nowa historia, przeł. G. Siwek, Warszawa 2002, s. 172.

${ }^{47}$ Niemniej partia Centrum już od dawna nie była też zwolenniczką demokracji. Po ogólnym trendzie katolicyzmu politycznego obecnym w międzywojennej Europie zaczęła stopniowo opowiadać się za zasadami autorytaryzmu i dyktatury w obawie przed bolszewizmem i rewolucją. Zob. J. Holzer, „Landbevölkerung und Nationalsozialismus. Eine soziologische Untersuchung 
Po marcowych wyborach duża część katolickich wyborców Centrum, a także niektórzy biskupi, wśród nich zwłaszcza kardynał Michael von Faulhaber (arcybiskup Monachium i Fryzyngi), reprezentowali coraz bardziej przychylną postawę wobec narodowych socjalistów. Hitler nie krył swoich zamiarów zarówno wobec Centrum, jak i Bawarskiej Partii Ludowej (BVP), prawicowej Niemieckiej Partii Państwowej (DStP) i protestanckiej Chrześcijańsko-Społecznej Służby dla Ludu (CSVd), których głosy również liczyły się w tej politycznej rozgrywce. Ugrupowania te miały stanowić jedynie spolegliwy instrument w jego rękach, którym pragnął zawładnąć, stosując pełną afektacji nacjonalistyczną retorykę. Powoływanie się na tradycje chrześcijańskie oraz prezentowanie siebie w aureoli nieskazitelnego męża opatrznościowego, zbawcy i kanclerza ludu (Volkskanzler) ${ }^{48}$, który pragnie rozejmu partyjnego (Bürgerfrieden), dopełniało obrazu fałszywych umizgów kanclerza ${ }^{49}$. Przypodobaniu się elektoratowi mieszczańsko-konserwatywnemu służyły też wizyta wicekanclerza von Papena u kardynała Adolfa Bertrama $^{50}$ (18 marca 1933 roku) oraz manifestowanie przez władze przy każdej oficjalnej okazji pozytywnego nastawienia wobec Kościoła katolickiego w Niemczech. Pożyteczne dla Hitlera okazały się ponadto rozmowy, jakie przeprowadził w dniach 20 i 22 marca z kierownictwem Centrum, zwłaszcza z przewodniczącym partii prałatem Ludwigiem Kaasem oraz jego bliskim współpracownikiem Adamem Stegerwaldem. Obaj ci politycy zgodnie przychylili się do argumentacji kanclerza, który postulował przeprowadzenie koniecznych zmian Konstytucji w trybie ustawodawczym. Gwarantował przy tym trwałość istnienia landów i -

der politischen Willensbildung in Schleswig-Holstein 1918-1932”, Rudolf Heberle, Stuttgart 1963 [recenzja], „Przegląd Historyczny” 57, 1966, nr 1, s. 172-174; R.J. Evans, Nadejście..., s. 358; J. Becker, Zentrum und Ermächtigungsgesetz 1933, „Vierteljahrshefte für Zeitgeschichte” 1961, nr 2, s. 195-210; R. Morsey, Hitlers Verhandlungen mit der Zentrumsführung am 31. Januar 1933. Dokumentation, „Vierteljahrshefte für Zeitgeschichte” 1961, nr 2, s. 182-194; H. Wolf, Reichskonkordat für Ermächtigungsgesetz?, „Vierteljahrshefte für Zeitgeschichte” 2012, nr 2, s. 169-200.

48 Swoistej deifikacji postaci kanclerza służyło powołane 11 marca 1933 roku Ministerstwo Rzeszy ds. Oświecenia Narodu i Propagandy (Reichsministerium für Volksaufklärung und Propaganda) pod kierunkiem zausznika Hitlera, Josepha Goebbelsa, które miało być głównym ośrodkiem agitacji społeczeństwa. Utworzenie nowego ministerstwa spotkało się na początku z oporem konserwatywnych koalicjantów, zwłaszcza von Papena i Hugenberga, którzy zarzucali Hitlerowi, że złamał przedwyborczą obietnicę, iż nie będzie zmieniał składu gabinetu. Ostatecznie jednak nacjonaliści musieli ulec polityce faktów dokonanych szefa rządu. Zob. Joseph Goebbels vor der Presse über die Errichtung des Reichspropagandaministeriums, 15. 3. 1933, [w:] Deutsche Geschichte..., red. W. Michalka, s. 78-80; L. Biały, Izba Kultury Rzeszy w systemie propagandy hitlerowskiej, „Studia nad Faszyzmem i Zbrodniami Hitlerowskimi” 12, 1987, s. 241 n.; D. Irving, Goebbels. Mózg Trzeciej Rzeszy, przeł. B. Zborski, Gdynia 1998, s. 277 n.; D.G. Williamson, The Third Reich, London 2003, s. 52 n.; R. G. Reuth, op. cit., s. 192.

49 Zob. A. Wucher, Marksteine der deutschen Zeitgeschichte 1914-1945, Darmstadt 1991, s. $121 \mathrm{n}$

50 Szerzej na temat stosunku wrocławskiego kardynała do narodowego socjalizmu zob. K. Jonca, Kardynat Bertram a nazizm, „Studia nad Faszyzmem i Zbrodniami Hitlerowskimi” 24, 2001, s. 293 n. 
w warunkowym sformułowaniu - wszystkich sił ,propaństwowych”, ochronę praw grup wyznaniowych i stanu urzędniczego, a także nienaruszalność praw prezydenta Rzeszy ${ }^{51}$.

Dodatkowym bodźcem, który skłonił polityków Centrum do zgodzenia się na współpracę z nazistami, było stanowisko samego Watykanu. Wydaje się, że Stolica Apostolska wykazywała w tamtym czasie większe zainteresowanie podpisaniem konkordatu z Rzeszą ${ }^{52}$ (wzorowanego na układach laterańskich z 1929 roku) niż na wspieraniu chylącej się ku upadkowi katolickiej partii. Hitler, świadomy tej strategii Stolicy Apostolskiej, oprócz obietnic wprowadzenia w kraju szkół wyznaniowych obiecał zachowanie obowiązującej mocy konkordatów zawartych wcześniej przez Watykan z takimi landami, jak Bawaria (1924), Badenia (1932) oraz Prusy (1929). Tej grze politycznej kanclerza towarzyszyło ustawiczne podkreślanie przez przedstawicieli rządu bezdyskusyjnej roli chrześcijaństwa, które miało stanowić najważniejszy element niemieckiego „ducha narodowego”. Za pomocą narodowej frazeologii i eksponowania wartości konserwatywnych naziści próbowali jednocześnie poprawić swój wizerunek za granicą, a szczególnie w oczach papiestwa $^{53}$. W rezultacie Centrum opowiedziało się ostatecznie za taktyczną współpracą z Hitlerem, mimo że stanowisko tego ugrupowania nie było do końca jednolite ${ }^{54}$. Deputowani katoliccy zgodzili się poprzeć kanclerza również pod wpływem obietnic von Papena, który zapewniał, że konserwatyści nadal będą starali się zapobiegać zbyt radykalnym działaniom nazistów oraz że nowe regulacje

51 Zob. P. Longerich, Hitler. Biografia, przeł. M. Antkowiak, Warszawa 2017, s. 371; M. Broszat, Der Staat..., s. 115; H.U. Thamer, op. cit., s. 272 n.

52 Konkordat między Stolicą Apostolską a Rzeszą Niemiecką ostatecznie podpisano 20 lipca 1933 roku; wszedł on w życie 10 września 1933 roku. Zob. T. Włodarczyk, Konkordaty. Zarys historii ze szczególnym uwzględnieniem XX wieku, Warszawa 1986, s. 233 n.; J. Krasuski, Problemy katolicyzmu niemieckiego (na marginesie książek: Deutscher Katholizismus nach 1945; E. Fischer, Trennung von Staat und Kirche; H. Müller, Katholische Kirche und Nationalsozialismus; G. Lewy, Die katholische Kirche und das Dritte Reich; H. Lutz, Demokratie im Zwielicht), „Przegląd Zachodni" 1965, nr 1, s. 191 n.; A. Klafkowski, Konkordat z Niemcami z 1933 r. jako zagadnienie prawa międzynarodowego, „Przegląd Zachodni” 1949, nr 12, s. 608 n.; Z. Zieliński, Taktyka władz niemieckich $w$ sprawie wyktadni art. 31 konkordatu z Trzecia Rzesza w czasie od jego parafowania do ratyfikacji (8 VII-10 IX 1933 r.), „Studia nad Faszyzmem i Zbrodniami Hitlerowskimi” 22, 1999, s. 215 n.; M. Podkowiński, W kręgu Hitlera, Warszawa 1987, s. 222 n.

${ }_{53}$ M. Broszat, Der Staat..., s. 115.

${ }^{54}$ Przeciwko przyjęciu ustawy początkowo protestował wywodzący się z tego ugrupowania były kanclerz Heinrich Brüning. Niemniej później zmienił zdanie i twierdził, podobnie jak Kaas, że kontestacyjne postępowanie Centrum i tak nic by nie zmieniło. W wypadku odrzucenia nadzwyczajnych pełnomocnictw frakcję i partię czekałyby nieprzyjemne następstwa. Hitler dysponował bowiem niezbędnymi środkami, aby aresztować wystarczającą liczbę deputowanych do Reichstagu, aby w ten sposób uzyskać potrzebną większość głosów. Pozostawało zatem tylko jedno wyjście, a mianowicie zabezpieczenie się przed najgorszym. Zob. G. Mann, Niemieckie dzieje w XIX $i$ XX wieku, przeł. A. Kopacki, Olsztyn 2007, s. 456. A.L. Mannes, Heinrich Brüning. Leben, Wirken, Schicksal, München 1999, s. 186 n.; M. Hesemann, Pius XII wobec Hitlera, przeł. R. Zajączkowski, Kraków 2010, s. 104-105. 
prawne będą miały charakter jedynie przejściowy. Podobne stanowisko jak Centrum zajęła również BVP, której kierownictwo uważało, że tylko idąc na ustępstwa wobec Hitlera, utrzymają swoją pozycję i wpływ na rządy krajowe w Bawarii ${ }^{55}$.

Składająca się pięciu zwięzłych artykułów tak zwana ustawa o pełnomocnictwach (oficjalnie „ustawa o zabezpieczeniu narodu i państwa przed nieszczęściem" - Gestetz zur Behebung der Not von Volk und Reich $)^{56}$, nad którą gabinet w ciągu ostatniego miesiąca wielokrotnie się naradzał, przewidywała, że rząd Rzeszy będzie mógł w przyszłości w trybie pozakonstytucyjnym, to znaczy bez udziału parlamentu, uchwalać ustawy, w tym te odnoszące się do kwestii budżetu i kredytów zagranicznych (art. 1). Ponadto rząd miał otrzymać wyraźne uprawnienie do stanowienia przepisów odbiegających od Konstytucji, o ile tylko nie dotyczy to instytucji Reichstagu i Reichsratu (Rady Rzeszy — izby wyższej parlamentu złożonej z przedstawicieli rządów krajowych) ani też ,praw prezydenta Rzeszy" (art. 2). Poprzez to subtelne rozróżnienie między instytucjami (zabrakło gwarancji odnoszących się do urzędu prezydenta, to jest sposobu jego wybierania i zastępstwa) dokonano pierwszego kroku w stronę tego, by w razie śmierci Hindenburga móc wyznaczyć jego sukcesora w sposób pozakonstytucyjny. Tekst uchwał miał „opracować” kanclerz, a zatwierdzone akty legislacyjne miały wchodzić w życie następnego dnia, o ile nie kolidowały z innymi regulacjami, po ich ogłoszeniu i publikacji w Dzienniku Ustaw Rzeszy (art. 3). Gabinet rezerwował sobie również prawo do zawierania umów z obcymi państwami i przejęcia uprawnień legislacyjnych w tym zakresie, bez konieczności uzyskania zgody „ciał uczestniczących w uchwalaniu ustaw". Rada ministrów miała ponadto wydawać odpowiednie przepisy wykonawcze w celu ,realizacji tych umów”, co w praktyce dawało jej swobodę prowadzenia polityki zagranicznej (art. 4). Rozpatrywane regulacje miały obowiązywać przez cztery lata (do 1 kwietnia 1937 roku), lecz traciły moc, także „gdyby obecny rząd Rzeszy został zastąpiony innym” (art. 5). Tak więc w razie rozpadu gabinetu Hitlera-Hugenberga prezydent mógł zażądać wycofania owych prerogatyw, czyniąc użytek ze swojego prawa do mianowania kanclerza oraz ministrów.

Można powiedzieć, że ustawa o nadzwyczajnych pełnomocnictwach jak najbardziej zawierała pewne zabezpieczenie przed niepohamowanym poszerzaniem władzy przez Hitlera kosztem jego konserwatywnych koalicjantów. Hitlerowi jednak służyła ona do wyswobodzenia się z wszelkiej odpowiedzialności przed Reichstagiem. Dysponował on ponadto własną większością parlamentarną i nie był już zdany na rozporządzenia wyjątkowe prezydenta. W rezultacie pozycja

55 Szerzej zob. K. Fiedor, Bawarska Partia Ludowa na tle katolickiego ruchu politycznego w Niemczech 1918-1933, „Śląski Kwartalnik Historyczny Sobótka” 1966, nr 1-3, s. 296 n.

56 Ustawa o zabezpieczeniu narodu i państwa przed nieszczęściem z 24 III 1933 r., [w:] Historia ustroju..., s. 170; Reichsgesetzblatt I 1933, s. 141. 
Hindenburga, na której budowali politycy prawicowo-konserwatywni, starający się „ująć Hitlera w ramy”, siłą rzeczy ulegała znacznemu osłabieniu ${ }^{57}$.

Zaplanowane posiedzenie Reichstagu odbyło się 23 marca 1933 roku. O „brunatnym” charakterze nowego parlamentu świadczyły widoczne wszędzie w operze Krolla flagi ze swastyką oraz groźne jednostki SA oraz SS, które obstawiły w gmachu wszystkie wyjścia, nie pozwalając deputowanym opuścić sali, dopóki nie zostaną przekazane rządowi nadzwyczajne pełnomocnictwa ${ }^{58}$. Hitler, ubrany na tę okazję w partyjny strój NSDAP, wygłosił swoją jedyną w karierze politycznej mowę parlamentarną. Żarliwą perorę zaczął od ubolewania nad „upadkiem”, jakiego naród niemiecki rzekomo doznawał w ciągu ostatnich lat, po czym zaczął omawiać program „odbudowy narodu i Rzeszy”. Temu właśnie celowi - „dobrobytowi naszych gmin i landów”, mówił kanclerz — będzie służyć przedłożona ustawa, która miała pozwalać rządowi zapewniać „od tej chwili po wsze czasy jednolitość intencji politycznej w Rzeszy i jej landach”. Gabinet, jak wyjaśniał, dla przeciwdziałania „,całkowitej deprecjacji ciał ustawodawczych” wskutek coraz to nowych wyborów, chce wskazać drogę, ,która sprawi, że raz sformułowana wola narodu będzie miała jednolite konsekwencje w Rzeszy i w landach”. Hitler zapowiadał jednocześnie ,polityczne odtrucie naszego życia publicznego", które przyniesie „gruntowne uzdrowienie moralne narodowego organizmu”. Oświadczył, że oba wyznania chrześcijańskie są „,najważniejszymi czynnikami podtrzymującymi nasz charakter narodowy"59, a także godził się na zasadę „nieusuwalności sędziów”, która wszakże, jak niedwuznacznie podkreślił, musi iść w sukurs $\mathrm{z}$,elastycznością w wydawaniu wyroków dla dobra społeczeństwa". Zapowiedzi Hitlera w sferze polityki gospodarczej były nadzwyczaj mgliste - wspominał o „wspieraniu prywatnej inicjatywy”, „uznaniu własności”, jak też o zmniejszeniu obciążeń podatkowych. Akcentował także podjęcie działań w kierunku ,ratowania niemieckiego chłopa”, ,włączania armii bezrobotnych w proces produkcyjny" i zabezpieczenia klasy średniej ${ }^{60}$.

W dalszej części swego przemówienia Hitler zapewniał, że przyjęcie proponowanej uchwały nie spowoduje zlikwidowania Reichstagu i Reichsratu ani nie będzie zagrażało specjalnym uprawnieniom prezydenta oraz samodzielności krajów związkowych. Następnie Hitler uspakajał partie zebrane w parlamencie,

57 Zob. P. Longerich, op. cit., s. 370-371; H. Hattenhauer, op. cit., s. 317; L. Janicki, Projekty ustawy o stanie wyjątkowym w Niemieckiej Republice Federalnej, „Przegląd Zachodni” 1966, nr 1, s. 4; K. Grzybowski, Niemcy hitlerowskie, [w:] Pod znakiem ..., s. 72.

58 Zob. Ch.G. v. Krockow, Hitler und seine Deutschen, Berlin 2001, s. 153; A. Bullock, Hitler i Stalin. Żywoty równoległe, przeł. M. Lipska, J. Mianowski, M. Rudowski, Warszawa 1994, s. $320-321$.

59 Zob. H. Brüdigam, op. cit., s. 45.

${ }^{60} \mathrm{~W}$ sprawie polityki zagranicznej Hitler podnosił natomiast, że jego gabinet dąży do rozbrojenia, pokoju i przyjaznych stosunków międzynarodowych. Deklarował zarazem, że będzie prowadził starania o zbliżenie „,czterech mocarstw: Anglii, Francji, Włoch i Niemiec” oraz że zależy mu również na utrzymywaniu korzystnych relacji z ZSRR. Zob. P. Longerich, op. cit., s. 371-372. 
że po dokonaniu stosownej zmiany ustawodawczej ich dalsza pokojowa egzystencja oraz współpraca polityczna nie będą thumione przez „rząd narodowego powstania". Dowodził ponadto, że specjalne uprawnienia nie będą zbyt często wykorzystywane przez gabinet, ponieważ i tak ma on wystarczającą większość w Reichstagu. Komentując możliwość odrzucenia przez opozycję proponowanych przepisów, stwierdził, że taki krok zostanie potraktowany jako „manifestacja oporu" i w konsekwencji będzie oznaczać wojnę parlamentu z gabinetem.

Mimo nękania i atmosfery zastraszenia stworzonej przez obecnych na sali esamanów i esesmanów posłowie SPD próbowali stawić opór wobec dyktatorskich zapędów Hitlera. Wyrazem takiej postawy było przemówienie znanego socjaldemokraty Ottona Welsa, który wziął w obronę demokratyczne ideały państwa prawa w imię wartości humanizmu i sprawiedliwości. Akcentował znaczenie ,prawdziwej wspólnoty narodowej”, w ramach której przestrzegane są zasady wolności i równości dla wszystkich obywateli ${ }^{61}$. Podkreślał przy tym: „Można nam zabrać wolność i życie, ale nie honor. [...] Żadna ustawa o pełnomocnictwach nie da wam władzy do unicestwienia wiecznych i niezniszczalnych idei". Na zakończenie Wels pozdrowił ,prześladowanych i uciśnionych”: „Wasza niezłomność i wierność zasługuje na podziw. Wasza odwaga głoszenia swoich poglądów i niezachwiana nadzieja to gwarancja jaśniejszej przyszłości”. Odpowiedział mu, jak można przeczytać w protokole obrad, wielokrotny ,śmiech narodowych socjalistów". Wels był ostatnim, który przed mroczną epoką następnych dwunastu lat opowiedział się z trybuny Reichstagu za demokracją i praworządnością ${ }^{62}$.

Hitler zareagował na te enuncjacje $\mathrm{z}$ nieskrywanym oburzeniem i pogardą, choć maszynopis przemówienia Welsa dostarczono mu już wcześniej. W swej replice, w której kanclerz w pełni odsłonił twarz brutalną i chciwą władzy, cynicznie zarzucił opozycji, że z podobnymi mowami o praworządności powinna była ona występować dużo wcześniej: „Cóż, przychodzicie późno, ale zawsze. O tych pięknych teoryjkach, które nam pan tu przed chwilą obwieścił, panie pośle, historia świata dowiaduje się nieco zbyt późno". Zamiast tego w ocenie Hitlera zmarnowane zostało czternaście lat, które rzekomo obfitowały w same klęski i niepowodzenia narodu. Następnie z pozycji rewolucyjnych atakował socjaldemokratów, którzy mieli zdradzić Niemcy oraz przyczynić się do upadku standardów prawnych w państwie. Hitler dodawał jednocześnie, wołając szyderczo do posłów SPD: „Cóż z was za płaczliwe mimozy, panowie. Nie nadajecie się do dzisiejszych czasów, skoro już teraz mówicie o prześladowaniach”. Na koniec, zwracając się do opozycyjnych deputowanych, skonstatował, że wcale nie muszą oni głosować za ustawą, gdyż jest przekonany, że: „Niemcy i tak będą wolne,

${ }^{61}$ Zob. O. Wels: Gegen das Ermächtigungsgesetz, [w:] Vom Gestern zum Heute. 200 Jahre deutsche Geschichte in Texten und Dokumenten, red. R. Wildermuth, München 1987, s. 129-130.

62 Zob. V. Ullrich, Hitler. Narodziny zła 1889-1939, przeł. M. Antkowiak, Warszawa 2015, s. 567; N. Frei, Państwo wodzowskie. Rzady narodowosocjalistyczne w latach 1933-1945, przeł. R. Marszałek, Warszawa 2000, s. 56-57; O. Wels: Gegen ..., s. 129-130. 
ale nie dzięki wam!”, a posłów wzywa się tu jedynie do „zatwierdzenia tego, co i tak mógłby sobie wziąć". Odpowiedź kanclerza, w której dobitnie oznajmił, że za jego rządów wszelkie normy związane z podziałem władz i państwem prawa zostaną unieważnione, a obietnica „legalnej ścieżki” okazała się jedynie zwodniczym pustosłowiem, została przyjęta gromkimi owacjami przez deputowanych NSDAP obecnych na posiedzeniu. Skwitowali oni przemówienie Hitlera długimi i burzliwymi okrzykami „Heil!”. Podobnie aklamacyjne stanowisko zajęli koalicjanci z DNVP ${ }^{63}$.

Po naradzie stronnictw doszło do głosowania nad ustawą. Deputowani Centrum (72 osoby) zdecydowali się poprzeć przepisy o nadzwyczajnych pełnomocnictwach dla kanclerza. Dzięki poparciu tej partii, BVP, DStP i CSVd, a także partii rolniczo-chłopskich (Bauernpartei i Landbundu) głosowanie nad ustawą zakończyło się pełnym sukcesem rządu — 444 głosów (69\%) przeciwko 94 głosom posłów SPD ${ }^{64}$. Kanclerz i jego gabinet otrzymali specjalne uprawnienia na cztery lata, a stosowne prawo weszło w życie już 24 marca $^{65}$. W wyniku tych regulacji rząd Rzeszy uzyskał carte blanche, jeśli chodzi o dalsze przeprowadzanie procesu „ujednolicania”, czyli w praktyce uniformizacji rzeczywistości społeczno-politycznej Niemiec. Od tego czasu tryb legislacyjny oprócz ustaw parlamentu obejmował nade wszystko dekrety rady ministrów (tak zwane ustawy rządowe) oraz bezpośrednie zarządzenia Hitlera (Führererlasse) ${ }^{66}$. Te dwie ostatnie formy aktów prawnych stopniowo zdominowały niemiecki porządek ustrojowy. Przyjęte mocą pełnomocnictw przez gabinet uchwały, które - jak wspomniano - miał

${ }^{63}$ Zob. V. Ullrich, op. cit., s. 568; P. Longerich, op. cit., s. 372-373; H.U. Thamer, op. cit., s. $277-278$.

${ }^{64}$ Reszta ich studwudziestoosobowej frakcji wyemigrowała, przebywała w tak zwanym areszcie ochronnym lub zgłosiła swą nieobecność ze względów osobistego bezpieczeństwa. Ponadto Hermann Göring jako przewodniczący Reichstagu zmniejszył kworum z 432 do 378, nie uwzględniając przedstawicieli KPD, mimo że wszyscy zostali legalnie wybrani. Była to arbitralna decyzja, która nie znajdowała żadnej podstawy prawnej. Niemniej nawet po tym nielegalnym manewrze do przeforsowania projektu naziści i tak potrzebowali jedynie głosów partii Centrum. Zob. P. Longerich, op. cit., s. 373; R.J. Evans, Nadejście..., s. 357-358.

${ }^{65}$ Reichstag 30 stycznia 1937 roku przedłużył tę ustawę do 1 kwietnia 1941 roku (Gesetz zur Verlängerung des Gesetzes zur Behebung der Not von Volk und Reich). Została ona zaś prolongowana 30 stycznia 1939 roku do 10 maja 1943 roku. Od dokładnie tego samego dnia, zgodnie z „dekretem Führera o ustawodawstwie rządowym” (Führererlass), ustawa ta miała obowiązywać aż do odwołania. Hitler miał być odtąd odpowiedzialny tylko przed „Bogiem i historią”. Zob. 30. Janauar 1937: Erste Verlängerung des Ermächtigungsgesetzes, [w:] Das „Ermächtigungsgesetz” vom 24. März 1933. Quellen zur Geschichte und Interpretation des ,, Gesetzes zur Behebung der Not von Volk und Reich", red. R. Morsey, Düsseldorff 1992, s. 114; 30. Januar 1939: Zweite Verlängerung des Ermächtigungsgesetzes, [w:] Das „Ermächtigungsgesetz”..., s. 116; 10. Mai 1943: Erlass Hitlers über die Regierungsgesetzgebung, [w:] Das ,Ermächtigungsgesetz”..., s. 126.

${ }^{66}$ Szerzej zob. „,Führer-Erlasse“ 1939-1945. Edition sämtlicher überlieferter, nicht im Reichsgesetzblatt abgedruckter, von Hitler während des Zweiten Weltkrieges schriftlich erteilter Direktiven aus den Bereichen Staat, Partei, Wirtschaft, Besatzungspolitik und Militärverwaltung, red. M. Moll, Stuttgart 1997.

Studia nad Autorytaryzmem i Totalitaryzmem 41, nr 4, 2019

(C) for this edition by CNS 
„opracować” kanclerz ${ }^{67}$, „mogły odbiegać od konstytucji Rzeszy”, co oznaczało ubezwłasnowolnienie i marginalizację Reichstagu, który w praktyce sam abdykował $^{68}$. Za Renem Léon Blum mówił o godnym ubolewania ,samobójstwie, harakiri popełnionym przez suwerenny parlament na ołtarzu dyktatora"69. Ze względu na szczególną pozycję kanclerza w ówczesnym systemie politycznym Niemiec (tak zwane rządy kanclerskie) nadzwyczajne prerogatywy zostały zagarnięte przez samego Hitlera, który mógł swobodnie dysponować zdobytymi przywilejami. Posługiwał się odtąd prezydentem Hindenburgiem niczym ,pieczątką" lub całkowicie go pomijał przy stanowieniu prawa ${ }^{70}$.

Tego samego dnia, to jest 23 marca 1933 roku, ustawę przegłosował także bezbronny i zdominowany przez nazistowskich nominatów Reichsrat. Reichstag, a przede wszystkim partie mieszczańskie, głosując zgodnie z wolą Hitlera, zadecydowały jednocześnie o własnym losie, który dopełnił się kilka miesięcy później poprzez likwidację tych stronnictw przez reżim. Żałosna apologia polityków Centrum, którzy podkreślali potem, że Ermächtigungsgesetz miała charakter jedynie formalny, ponieważ już dekret z 28 lutego 1933 roku zapoczątkował w kraju dyktaturę, nie jest wystarczającym moralnym uzasadnieniem ich wstydliwej współpracy z Hitlerem. Nie wykorzystali bowiem oni sposobności wyrażenia choćby symbolicznego i zarazem etycznego sprzeciwu wobec totalitarnych zapędów nazistów. Co więcej, nadali poczynaniom Hitlera sztafaż legalizmu.

Uchwalenie ustawy o pełnomocnictwach stanowiło zakończenie pierwszego etapu zdobywania pełni władzy przez Hitlera. Ten akt prawny, wraz z obowiązującą „ustawą o pożarze Reichstagu” z 28 lutego 1933 roku był kamieniem milowym na drodze do likwidacji demokracji parlamentarnej w Niemczech. Nikt już nie mógł zagrozić hegemonii NSDAP, gdyż istnienie jakiejkolwiek opozycji politycznej w tych warunkach stawało się praktycznie niemożliwe. Odnosząc

${ }^{67}$ Duży wpływ na redagowanie projektów dekretów miał Hans Heinrich Lammers, czyli szef Kancelarii Rzeszy, a ministrowie kurendą wyrażali swą opinię, ale też zabiegali o potrzebne im ustawy rządowe (często bezskutecznie starając się w tych sprawach o uzyskanie audiencji u kanclerza). Lammers jako de facto jedyny łącznik między Führerem a jego ministrami w naturalny sposób uzyskał przemożny wpływ na to, jak akty legislacyjne były przedstawiane Hitlerowi. Jeśli uznał, że Hitler jest zbyt zajęty innymi, niecierpiącymi zwłoki sprawami państwowymi, akty prawne przygotowywane nierzadko przez długie miesiące po prostu ignorowano bądź też odkładano na później; czasami w ogóle już do nich nie wracano. Zdarzało się, że Hitler interweniował, wtrącając się w najdrobniejsze szczegóły, po otrzymaniu jakiejś jednostronnej informacji o nowym prawie, którą mu podsuwano. Rezultatem były coraz bardziej arbitralne decyzje, jako że kształtująca się stopniowo spersonalizowana forma rządów Hitlera stawała w coraz jaskrawszym i nieuniknionym konflikcie z biurokratyczną potrzebą uregulowanych norm oraz jasno zdefiniowanych procedur. Zob. I. Kershaw, op. cit., s. 466-467; Die Gestezgebung auf Grund des Ermächtigungsgesetzes 1933-1945 [w:] Das ,Ermächtigungsgesetz”..., s. 128.

${ }^{68}$ K. Gründberg, Adolf Hitler. Biografia Führera, Warszawa 1988, s. 115-116.

${ }^{69}$ Cyt. za: M. Kitchen, Trzecia Rzesza. Charyzma i wspólnota, przeł. L. Otrębski, Warszawa 2012, s. 92.

${ }^{70}$ Zob. R.J. Evans, Nadejście..., s. 360; F. Ryszka, op. cit., s. 207. 
sukces w Reichstagu, Hitler uniezależnił się jednocześnie od prezydenta ${ }^{71}$ oraz swoich konserwatywnych koalicjantów, którzy nie byli mu już wówczas do niczego potrzebni. Nie musiał też odtąd polegać na nadzwyczajnych zarządzeniach Hindenburga, aby przekształcić Niemcy w państwo totalitarne ${ }^{72}$. Oznaczało to definitywną porażkę koncepcji „oswajania”, której kluczowym elementem była możliwość użycia prerogatyw prezydenta ${ }^{73}$. Pełnomocnictwa, wynikające z praktycznych i czysto prawniczych następstw stosowania art. 48 Konstytucji, zawierają w sobie także pierwiastek charyzmatyczny w kontekście przyszłej ustrojowej pozycji Führera w III Rzeszy.

Wymieniony w ustawie rząd to w zasadzie sam Hitler, który w swoich działaniach nie musiał już oglądać się na Reichstag ${ }^{74}$, prezydenta ani na nawet na wolę społeczeństwa, ponieważ prawo ogłaszane przez gabinet nie mogło zostać zakwestionowane przez żaden plebiscyt. Przywódca stawał się od tej pory całkowicie niezależną instancją władzy, niepodlegającą jakiejkolwiek kontroli politycznej. Ermächtigungsgesetz doskonale spełniła swoją funkcję, jeśli chodzi o stabilizację kształtującego się wówczas totalitarnego reżimu i zasady samowładztwa jednego człowieka (Führerprinzip). Ustawa ta zadośćuczyniła jednocześnie pragnieniom konserwatystów, którzy usprawiedliwiając nadzwyczajne kroki rządu, powoływali się na tradycje pozytywizmu prawniczego ${ }^{75} \mathrm{i}$ aspekty legalistycznej kontynuacji związane z doktryną prawa państwowego, wskazując chociażby na zachowanie przez rząd konstytucji weimarskiej ${ }^{76}$. Z tego też powodu lekceważyli oraz sankcjonowali mnożące się wciąż akty przemocy i gwałty, które były immanentnym składnikiem procesu Machtergreifung. Hitler nie był już zdany na sojusz z konserwatystami, choć dla zachowania pozorów w pierwszym okresie

${ }^{71}$ Hindenburg promulgował ustawę o pełnomocnictwach, mimo że zgodnie z art. 73 Konstytucji miał możliwość poddania tego aktu normatywnego pod referendum ludowe. Przyczynił się on w efekcie do uprawomocnienia swoistego zamachu stanu Hitlera, a tym samym do ,zasuspendowania” Konstytucji. Zob. L. Janicki, Kilka uwag na temat konstytucyjnoprawnych aspektów dojścia Hitlera do władzy, [w:] Faszyzm niemiecki z perspektywy pótwiecza. Materiały i studia, red. A. Czubiński, Poznań 1985, s. 145.

72 J.C. Fest, Hitler..., s. 53.

73 V. Ullrich, op. cit., s. 569.

74 Parlament wkrótce stał się zgromadzeniem reprezentantów Hitlera, członków „państwowej elity partii”. Ponadto Reichstag odbywał swoje sesje niezwykle rzadko i stanowił jedynie serwilistyczne audytorium klakierów. Deputowani z zachwytem wysłuchiwali tylko kolejnych przemówień Hitlera oraz lubowali się śpiewaniem nazistowskich pieśni, jak chociażby popularnej wtedy Horst-Wessel-Lied (dlatego też zgromadzenie to niekiedy nazywano ironicznie „najlepiej w świecie opłacanym chórem męskim”). Zob. J. Baszkiewicz, Powszechna historia ustrojów państwowych, Gdańsk 1998, s. 354.

75 Szerzej zob. M. Zmierczak, Pozytywizm prawniczy a prawnicy i prawo w Trzeciej Rzeszy - powojenna dyskusja niemieckich historyków i teoretyków prawa o przyczynach upadku prawa w czasach nazizmu, „Studia nad Faszyzmem i Zbrodniami Hitlerowskimi” 24, 2001, s. 5 n.

76 Por. A. Mycielski, op. cit., s. 129. 
zatrzymał ich jeszcze w składzie gabinetu ${ }^{77}$. W rezultacie koalicjanci sami stali się ofiarą propagandy władzy, która jedynie ze względów taktycznych przywdziewała maskę legalności oraz tradycji, dążąc w rzeczywistości do poddania narodu dyktaturze.

Hitler potrzebował niespełna dwóch miesięcy, aby ostatecznie przejąć władzę. Tempo, w jakim umacniał swoje rządy w Niemczech, było wprost niewiarygodne $^{78}$. Faktycznie to on kierował teraz państwem i nie był kontrolowany przez żaden inny ośrodek decyzyjny. Uprawnienia prezydenta miały już charakter czysto formalny i teoretyczny, skoro kanclerz mógł w każdej chwili zmienić konstytucję. Mówiąc wprost, znaczyło to, że Hitler wszedł na drogę dyktatury totalitarnej, a koncepcje autorytarne jego konserwatywnych sojuszników nie były już nawet przedmiotem dyskusji. Wkrótce nie mówiono już o ,rewolucji narodowej”, lecz „narodowosocjalistycznej"79. Ustawa o pełnomocnictwach odegrała też fundamentalną rolę w procesie glajchszaltowania społeczeństwa, które miało zostać poddane homogenizacji, a wszystkie dziedziny jego życia zamierzano podporządkować wykładni ideologicznej, jaką wyznawała NSDAP ${ }^{80}$. Podobnej uniformizacji miała zostać poddana struktura administracyjna państwa.

Rząd wykorzystał swe nowe uprawnienia 31 marca 1933 roku do promulagacji tymczasowego prawa o ,ujednoliceniu” landów z Rzeszą, potwierdzonego ustawą z 7 kwietnia tegoż roku. Sankcjonowały one jedynie to, co już się stało w całych Niemczech. Ustawa o pełnomocnictwach obowiązywała już w landach, których rządy nie musiały odtąd zważać na miejscowe parlamenty i mogły rządzić za pomocą dekretów. Namiestnicy Rzeszy (Reichsstatthalter), czyli mianowani w pozbawionych woli politycznej krajach związkowych (z wyjątkiem Prus $^{81}$ ) pełnomocnicy kanclerza, zostali wyposażeni w dyktatorskie kompetencje i sprawowali tam faktyczną władzę. Oznaczało to de facto kres długiej i owocnej tradycji niemieckiego federalizmu, który zastąpiła scentralizowana dyktatura ${ }^{82}$. „Ujednolicone” zostały organizacje, które w przyszłości miały maszerować krok w krok z NSDAP lub też same wolały się podporządkować, demonstrując gorliwe posłuszeństwo. Przejawem tego procesu była ustawa o odnowieniu kadry

77 V. Ullrich, op. cit., s. 569.

78 W tym względzie Hitler prześcignął nawet swojego „mistrza” Benita Mussoliniego, który potrzebował kilku lat, aby zdobyć nieograniczoną władzę we Włoszech i przekształcić to państwo na modłę totalitarną. Zob. M. Zmierczak, Spory o istotę faszyzmu. Dzieje i krytyka, Poznań 1988, s. 202.

79 Zob. H.U. Thamer, op. cit., s. 280-281; W. Benz, Historia ..., s. 24.

80 Zob. F.L. Carsten, The Rise of Fascism, London 1967, s. 155 n.

${ }^{81}$ W Prusach już od zamachu stanu von Papena z 20 lipca 1932 roku przeciwko lokalnemu rządowi demokratycznemu władzę pełnili ministrowie Rzeszy. Zob. W. Benz, Historia ..., s. 24; Papens Staatsstreich gegen Preussen im Sommer 1932, [w:] Frühe Warnungen vor dem Nationalsozialismus. Ein historisches Lesebuch, red. K. Schönhoven, H.J. Vogel, Bonn 1998, s. 285 n.; R. Sturm, Regierung Papen, „Informationen zur Politischen Bildung” 1998, nr 261, s. 56-57.

${ }^{82}$ M. Kitchen, op. cit., s. 92, 104. 
urzędniczej ${ }^{83}$ (razem z zarządzeniem wykonawczym określana jako „paragraf aryjski”), która zakładała usunięcie niewygodnych dla władz funkcjonariuszy, przede wszystkim pochodzenia żydowskiego, zatrudnionych w biurokracji państwowej. Niearyjscy urzędnicy mieli zostać niezwłocznie przeniesieni w stan spoczynku; ustalenia omawianej ustawy, która początkowo nie obejmowała wprawdzie żołnierzy frontowych z czasów I wojny światowej, z biegiem czasu stosowano również $\mathrm{w}$ stosunku do kombatantów i w innych dziedzinach aktywności publicznej (na przykład adwokatura, praktyka lekarska) ${ }^{84}$. Definicja „Żyda” należała przy tym wyłącznie do NSDAP ${ }^{85}$.

Można powiedzieć, że od lutego/marca 1933 roku w Niemczech przez dwanaście lat obowiązywał permanentny stan wyjątkowy (stan oblężenia cywilnego), regulowany przez normy prawa wojennego, które były uzasadnieniem stosowania terroru przeciwko oponentom politycznym i ,rasowym”. W tym celu na podstawie tego prawa 21 marca 1933 roku utworzono pierwszy obóz koncentracyjny w Dachau w Bawarii, który stał się potem wzorem dla wszystkich kolejnych. Ermächtigungsgesetz była niejako konstytucją III Rzeszy, a na pewno drogą do wprowadzenia dyktatury Hitlera i NSDAP. W sferze polityki przestały bowiem obowiązywać wszelkie gwarancje prawne, ustawowe czy kodeksy jurysdykcyjne. Od tej pory praktyka rządzenia opierała się wyłącznie na decyzjach arbitralnych (Massnahmen), za pomocą których właściwi urzędnicy realizowali swoje uprawnienia stosownie do własnej oceny sytuacji. Państwo stanu wyjątkowego było $\mathrm{w}$ tym sensie tożsame $\mathrm{z}$ tak zwanym państwem prerogatywnym (Massnahmenstaat), w którym swobody demokratyczne i prawo de facto przestały obowiązywać i chronić obywatela przed nadużyciami władzy ${ }^{86}$.

Po czterech miesiącach od uchwalenia Ermächtigungsgesetz nie było już związków zawodowych, a po pół roku nie było w Niemczech żadnych innych partii poza NSDAP. Zakaz działalności SPD z 22 czerwca 1933 roku położył kres wszelkim iluzjom ${ }^{87}$. Inne partie uprzedziły podobne ustalenia, decydując się na samorozwiązanie. Tam gdzie brakowało zrozumienia sytuacji, pomagał nazistowski terror. Ustawa z 14 lipca 1933 roku, zakazująca tworzenia nowych partii, oficjalnie przypieczętowała jedynowładztwo nazistów ${ }^{88}$. Tego samego dnia wydano także drugą ustawę, która przewidywała szczególny sposób legislacyjny, według którego rząd został uprawomocniony do bezpośredniego zwracania się do narodu $\mathrm{w}$ celu podjęcia

${ }^{83}$ Gesetz zur „Wiederherstellung des Berufsbeamtentums” vom 17. April 1933 (Auszüge), [w:] Der deutsche Faschismus in Quellen und Dokumenten, red. R. Kühnl, Köln 2000, s. 179-180.

84 W. Benz, Historia ..., s. 26, 106.

85 Ibidem, s. 25.

86 E. Fraenkel, Państwo prerogatywne..., s. 239-241.

87 Verbot der SPD vom 22. Juni 1933. Die amtliche Begründung. (Auszüge), [w:] Der deutsche Faschismus..., s. 180.

88 Zob. Gesetz gegen die Neubildung von Parteien, 14.7.1933, [w:] Deutsche Geschichte..., red. W. Michalka, s. 32; W. Benz, Historia ..., s. 28. 
niektórych decyzji za pomocą instytucji plebiscytu (Volksabstimmung) ${ }^{89}$. W wypadku uzyskania większości głosów społeczeństwa ustawę miał ogłaszać kanclerz. Należy jednak zauważyć, że referendum nie miało wiążącej dla rządu mocy prawnej. Było jedynie moralnym wezwaniem do narodu, który i tak, z powodu nieistnienia prawa inicjatywy ustawodawczej, nie miał większego wpływu na postanowienia władz wykonawczych ${ }^{90}$. Podkreśleniem ustrojowej pozycji ugrupowania hitlerowskiego była wydana 1 grudnia 1933 roku ,ustawa o zabezpieczeniu jedności partii

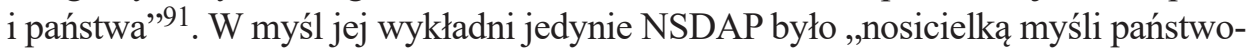
wych nierozerwalnie związanych z państwem" (Trägerin des deutschen Staatsgedankes). Stronnictwo nazistowskie zostało więc de iure organicznie połączone i tożsame z niemiecką ideą państwową ${ }^{92}$.

„Czyli teraz my jesteśmy panami”, podsumował Goebbels, który 23 marca 1933 roku, siedząc z Hitlerem w Kancelarii Rzeszy, ponownie wysłuchał w radiu jego odpowiedzi na wystąpienie parlamentarne deputowanego Welsa ${ }^{93}$. Uliczny terror bojówek nazistowskich osiągnął już wówczas tak dużą skalę, że było raczej jasne, co będzie dalej. Wels miał rację, przewidując, że Niemcy wkrótce przeistoczą się w państwo monopartyjne. Kolejne arbitralne poczynania Hitlera, których brutalnym apogeum była „noc długich noży”94 w czerwcu/lipcu 1934 roku, burzyły starannie zbudowaną fasadę i pozwalały widzom zajrzeć za kulisy sceny, gdzie on i pozostali protagoniści ,legalnej rewolucji” pokazali się bez przebrania i makijażu, z całą bezwzględną wolą opanowania władzy. Z początkiem sierpnia 1934 roku, kiedy Hitler został faktycznym następcą Hindenburga na stanowisku prezydenta Rzeszy, mógł sprawować już absolutne rządy dyktatorskie w państwie (Führerabsolutismus) ${ }^{95}$.

89 Gesetz über Volksabstimmung, vom 14. Juli 1933, [w:] Der Nationalsozialismus..., s. 61.

90 Zob. A. Mycielski, Stanowisko prawne Führera na tle ustroju Niemiec współczesnych, [w:] Pod znakiem..., s. 131.

${ }^{91}$ Gesetz zur Sicherung der Einheit von Partei und Staat, [w:] Deutsche Geschichte..., red. W. Michalka, s. 33.

92 L. Krajewski, Podstawy ustroju Trzeciej Rzeszy, [w:] Pod znakiem..., s. 155.

93 Zob. V. Ullrich, op. cit., s. 569; G. Botz, Das Ermächtigungsgesetz, ,Zeitungszeugen. Sammeledition: Die Presse in der Zeit des Nationalsozialismus" 2009, nr 3, s. 1.

94 Szerzej zob. H. Wolan, Kilka uwag o ,ujednolicaniu” spoleczno-politycznym w III Rzeszy w okresie puczu Röhma (1934 r.), ,Studia nad Faszyzmem i Zbrodniami Hitlerowskimi” 2, 1975, s. 322 n.; K.D. Bracher, W. Sauer, G. Schulz, op. cit., 1962, s. 938 n.; M. Cygański, SS w ruchu narodowosocjalistycznym i w III Rzeszy 1925-1945, Poznań 1978, s. 106 n.; J.C. Fest, Hitler..., s. $94 \mathrm{n}$.

95 Zob. R.J. Evans, Nadejście..., s. 360; J.C. Fest, Oblicze..., s. 81-82; M. Ruck, Führerabsolutismus und polykratisches Herrschaftsgefüge-Verfassungsstrukturen des NS-Staates, [w:] Deutschland 1933-1945. Neue Studien zur nationalsozialistischen Herrschaft, red. K.D. Bracher, M. Funke, H.A. Jacobsen, Bonn 1992, s. 32 n. 


\section{Bibliografia}

Baszkiewicz J., Powszechna historia ustrojów państwowych, Gdańsk 1998.

Becker J., Zentrum und Ermächtigungsgesetz 1933, „Vierteljahrshefte für Zeitgeschichte” 1961, nr 2.

Behning B., Z badań nad struktura grup w obozie koncentracyjnym Dachau (1933-1938), Opole 1988.

Benz W., Herrschaft und Gesellschaft im nationalsozialistischen Staat. Studien zur Struktur- und Mentalitätgeschichte, Frankfurt am Main 1990.

Benz W., Historia Trzeciej Rzeszy, przeł. R. Kazior, Warszawa 2006.

Bernaś T., Bernaś F., Podpalacze Reichstagu, Szczecin 1989.

Biały L., Izba Kultury Rzeszy w systemie propagandy hitlerowskiej, „Studia nad Faszyzmem i Zbrodniami Hitlerowskimi” 12, 1987.

Boldt H., Article 48 of the Weimar Constitution, its historical and political implications, [w:] German Democracy Democracy and the Triumph of Hitler: Essays in Recent German History, red. A. Nicholls, E. Matthias, London 1971.

Botz G., Das Ermächtigungsgesetz, „Zeitungszeugen. Sammeledition: Die Presse in der Zeit des Nationalsozialismus" 2009, nr 3.

Bracher K.D., Die Auflösung der Weimarer Republik. Eine Studie zum Problem des Machtverfalls in der Demokratie, Stuttgart-Düsseldorf 1955.

Bracher K.D., The technique of the national socialist seizure of power, [w:] The Road to Dictatorship: Germany 1918-1933, red. O. Wolff, London 1964.

Bracher K.D., Sauer W., Schulz G., Die nationalsozialistische Machtergreifung. Studien zur Errichtung des totalitären Herrschaftssystem in Deutschland 1933/34, Köln-Opladen 1962.

Broszat M., Die Machtergreifung. Der Aufstieg der NSDAP und die Zerstörung der Weimarer Republik, München 1990.

Broszat M., Nationalsozialistische Konzentrationslager 1933-1945, [w:] Die SS - das Herrschaftsinstrument. Befehl und Gehorsam, red. H. Buchheim, t. 2, München 1989.

Broszat M., Der Staat Hitlers. Grundlegung und Entwicklung seiner inneren Verfassung, München 1992.

Brüdigam H., Das Jahr 1933. Terrorismus an der Macht. Eine Dokumentation über die Errichtung der faschistischen Diktatur, Frankfurt am Main 1978.

Bullock A., Hitler i Stalin. Żywoty równoległe, przeł. M. Lipska, J. Mianowski, M. Rudowski, Warszawa 1994.

Burleigh M., Trzecia Rzesza. Nowa historia, przeł. G. Siwek, Warszawa 2002.

Butler R., Gestapo, przeł. M. Antosiewicz, Warszawa 2007.

Carlebach E., Hitler war kein Betriebsunfall. Hinter den Kulissen der Weimarer Republik. Die vorprogrammierte Diktatur, Frankfurt am Main 1978.

Carsten F.L., The Rise of Fascism, London 1967.

Chojnicka K., Kozub-Ciembroniewicz W., Doktryny polityczne XIX i XX wieku, Kraków 2000.

Crankshaw E., Gestapo, przeł. J. Dewitz, Warszawa 1995.

Cygański M., SS w ruchu narodowosocjalistycznym i w III Rzeszy 1925-1945, Poznań 1978.

Czubiński A., Lewica niemiecka w walce z dyktatura hitlerowska, Warszawa 1973.

Deutsche Geschichte 1933-1945. Dokumente zur Innen- und Aussenpolitik, red. W. Michalka, Frankfurt am Main 2002.

Das „Ermächtigungsgesetz” vom 24. März 1933. Quellen zur Geschichte und Interpretation des „, Gesetzes zur Behebung der Not von Volk und Reich”, red. R. Morsey, Düsseldorff 1992.

Evans R.J., Nadejście Trzeciej Rzeszy, przeł. M. Grzywa, Oświęcim 2015.

Evans R.J., Trzecia Rzesza u władzy, przeł. M. Grzywa, Oświęcim 2016.

Falter J.W., Hitlers Wähler, München 1991.

Studia nad Autorytaryzmem i Totalitaryzmem 41, nr 4, 2019

(C) for this edition by CNS 
Fest J.C., Hitler, t. 2. Führer, przeł. W. Jeżewski, Warszawa 1996.

Fest J.C., Oblicze Trzeciej Rzeszy, przeł. E. Werfel, Warszawa 1970.

Fiedor K., Bawarska Partia Ludowa na tle katolickiego ruchu politycznego w Niemczech 19181933, „Śląski Kwartalnik Historyczny Sobótka” 1966, nr 1-3.

Fraenkel E., Historical handicaps of German parliamentarism, [w:] The Road to Dictatorship: Germany 1918-1933, red. O. Wolff, London 1964.

Fraenkel E., Państwo prerogatywne, [w:] Faszyzmy europejskie (1922-1945) w oczach współczesnych $i$ historyków, red. J.W. Borejsza, przeł. A. Kreisberg et al., Warszawa 1979.

Frei N., Państwo wodzowskie. Rządy narodowosocjalistyczne w latach 1933-1945, przeł. R. Marszałek, Warszawa 2000.

Freyh R., Stärke und Schwäche der Weimarer Republik, Hannover 1963.

Frühe Warnungen vor dem Nationalsozialismus. Ein historisches Lesebuch, red. K. Schönhoven, H.J. Vogel, Bonn 1998.

„Führer-Erlasse” 1939-1945. Edition sämtlicher überlieferter, nicht im Reichsgesetzblatt abgedruckter, von Hitler während des Zweiten Weltkrieges schriftlich erteilter Direktiven aus den Bereichen Staat, Partei, Wirtschaft, Besatzungspolitik und Militärverwaltung, red. M. Moll, Stuttgart 1997.

Grunberger R., Historia społeczna III Rzeszy, przeł. W. Kalinowski, t. 1, Warszawa 1987.

Gründberg K., Adolf Hitler. Biografia Führera, Warszawa 1988.

Hattenhauer H., Die geistesgeschichtlichen Grundlagen des deutschen Rechts, Heidelberg 1983.

Hesemann M., Pius XII wobec Hitlera, przeł. R. Zajączkowski, Kraków 2010.

Historia ustroju państwa w tekstach źródłowych, red. B. Lesiński, J. Walachowicz, Warszawa-Poznań 1992.

Holzer J., „Landbevölkerung und Nationalsozialismus. Eine soziologische Untersuchung der politischen Willensbildung in Schleswig-Holstein 1918-1932”, Rudolf Heberle, Stuttgart 1963 [recenzja], „Przegląd Historyczny” 57, 1966, nr 1.

Horn W., Der Marsch zur Machtergreifung. Die NSDAP bis 1933, Königstein 1980.

Irving D., Goebbels. Mózg Trzeciej Rzeszy, przeł. B. Zborski, Gdynia 1998.

Janicki L., Kilka uwag na temat konstytucyjnoprawnych aspektów dojścia Hitlera do władzy, [w:] Faszyzm niemiecki z perspektywy pótwiecza. Materiały i studia, red. A. Czubiński, Poznań 1985.

Janicki L., Projekty ustawy o stanie wyjątkowym w Niemieckiej Republice Federalnej, „Przegląd Zachodni" 1966, nr 1.

Jäckel E., Panowanie Hitlera. Spetnienie światopogląu, przeł. A. Karszniewicz-Mazur, Wrocław 1989.

Jonca K., Areszt ochronny - pozasądowym środkiem walki z opozycją antyhitlerowska na Ślasku Opolskim (1933-1934), „Studia Śląskie” 12, 1967.

Jonca K., Kardynat Bertram a nazizm, „Studia nad Faszyzmem i Zbrodniami Hitlerowskimi” 24, 2001.

Jonca K., National socialist law in the Third Reich, „Studia nad Faszyzmem i Zbrodniami Hitlerowskimi" 5, 1980.

Kershaw I., Hitler, t. 1. 1889-1936. Hybris, przeł. P. Bandel, Poznań 2010.

Kitchen M., Trzecia Rzesza. Charyzma i wspólnota, przeł. L. Otrębski, Warszawa 2012.

Klafkowski A., Konkordat z Niemcami z 1933 r. jako zagadnienie prawa międzynarodowego, „Przegląd Zachodni” 1949, nr 12.

Kotłowski T., Historia Republiki Weimarskiej, Poznań 2004.

Krasuski J., Problemy katolicyzmu niemieckiego (na marginesie ksiązek: Deutscher Katholizismus nach 1945; E. Fischer, Trennung von Staat und Kirche; H. Müller, Katholische Kirche und Nationalsozialismus; G. Lewy, Die katholische Kirche und das Dritte Reich; H. Lutz, Demokratie im Zwielicht), „Przegląd Zachodni” 1965, nr 1.

Krockow Ch.G. v., Hitler und seine Deutschen, Berlin 2001.

Studia nad Autorytaryzmem i Totalitaryzmem 41, nr 4, 2019

(C) for this edition by CNS 
Labuda G., Dzieje Prus jako zagadnienie historiograficzne, „Przegląd Zachodni” 1995, nr 2.

Longerich P., Hitler. Biografia, przeł. M. Antkowiak, Warszawa 2017.

Maciejewski M., Ustanowienie rządów hitlerowskich $w$ ocenach niemieckich konserwatystów (1933-1934), „Przegląd Zachodni” 1992, nr 4.

Mann G., Niemieckie dzieje w XIX i XX wieku, przeł. A. Kopacki, Olsztyn 2007.

Mannes A.L., Heinrich Brüning. Leben, Wirken, Schicksal, München 1999.

Minuth K.H., Akten der Reichskanzlei. Regierung Hitlers 1933-1938, t. 1. 30 Januar bis 31 August 1933, Boppard am Rhein 1983.

Mommsen H., Aufstieg und Untergang der Republik von Weimar, Berlin 1998.

Morsey R., Hitlers Verhandlungen mit der Zentrumsführung am 31. Januar 1933. Dokumentation, „Vierteljahrshefte für Zeitgeschichte” 1961, nr 2.

Musioł T., Dachau 1933-1945, Katowice 1971.

Der Nationalsozialismus. Dokumente 1933-1945, red. W. Hofer, Frankfurt am Main 1957.

Pajewski J., W jakich okolicznościach został Hitler kanclerzem Rzeszy, „Przegląd Zachodni” 1949, nr 9-10.

Payne S.G., A History of Fascism 1914-1945, Madison 1995.

Pod znakiem swastyki. Polscy prawnicy wobec Trzeciej Rzeszy 1933-1939. Wybór pism, red. M. Maciejewski, M. Marszał, Kraków 2005.

Podkowiński M., W kręgu Hitlera, Warszawa 1987.

Pool J., Pool S., Hitlers Wegbereiter zur Macht. Die geheimen deutschen und internationalen Geldquellen, die Hitlers Aufstieg zur Macht ermöglichten, Bern 1979.

Rees L., Naziści. Ostrzeżenie historii, przeł. S. Kędzierski, Warszawa 1998.

Reichsgesetzblatt I 1933.

Reuth R.G., Goebbels, przeł. M. Misiorny, Warszawa 1996.

Roon G. v., Widerstand im Dritten Reich. Ein Überblick, München 1990.

Ruck M., Führerabsolutismus und polykratisches Herrschaftsgefüge-Verfassungsstrukturen des NS-Staates, [w:] Deutschland 1933-1945. Neue Studien zur nationalsozialistischen Herrschaft, red. K.D. Bracher, M. Funke, H.A. Jacobsen, Bonn 1992.

Ryszka F., Państwo stanu wyjątkowego. Rzecz o systemie państwa i prawa w Trzeciej Rzeszy, Wrocław 1985.

Salmonowicz S., Prusy. Dzieje państwa i spoleczeństwa, Poznań 1987.

Scheel K., 1933. Der Tag von Potsdam, Berlin 1996.

Schreckenberg H., Ideologie und Alltag im Dritten Reich, Frankfurt am Main 2003.

Sobolew A.I. et al., Międzynarodówka komunistyczna 1919-1943. Zarys historyczny, przeł. M. Wolska, Warszawa 1974.

Sturm R., Regierung Papen, „Informationen zur Politischen Bildung” 1998, nr 261.

Thamer H.U., Verführung und Gewalt. Deutschland 1933-1945, Berlin 1986.

Ullrich V., Hitler. Narodziny zła 1889-1939, przeł. M. Antkowiak, Warszawa 2015.

Vogt M., Die Weimarer Republik (1918-1933), [w:] Deutsche Geschichte. Von den Anfängen bis zur Wiedervereinigung, red. M. Vogt, Stuttgart 1991.

Vom Gestern zum Heute. 200 Jahre deutsche Geschichte in Texten und Dokumenten, red. R. Wildermuth, München 1987.

Wąsicki J., Polityka hitlerowska w zakresie administracji państwa, ,Studia nad Faszyzmem i Zbrodniami Hitlerowskimi” 11, 1987.

Węc J.J., Stanowisko Reichswehry wobec SA w okresie przejmowania władzy w Niemczech przez narodowych socjalistów (1933-1934), „Przegląd Zachodni” 1989, nr 5-6.

Wichert W., Krótki żywot Republiki Weimarskiej, czyli garść uwag na temat przyczyn upadku pierwszej demokracji niemieckiej, cz. 1, https:/historia.org.pl/2018/07/20/krotki-zywot-republikiweimarskiej-czyli-garsc-uwag-na-temat-przyczyn-upadku-pierwszej-demokracji-niemieckiejcz-1/ (dostęp: 20.12.2018).

Studia nad Autorytaryzmem i Totalitaryzmem 41, nr 4, 2019

(C) for this edition by CNS 
Williamson D.G., The Third Reich, London 2003.

Witkowski J., Gestapo. Anatomia systemu, Warszawa 2005.

Włodarczyk T., Konkordaty. Zarys historii ze szczególnym uwzględnieniem XX wieku, Warszawa 1986.

Wolan H., Kilka uwag o , ujednolicaniu” społeczno-politycznym w III Rzeszy w okresie puczu Röhma (1934 r.), „Studia nad Faszyzmem i Zbrodniami Hitlerowskimi” 2, 1975.

Wolf H., Reichskonkordat für Ermächtigungsgesetz?, „Vierteljahrshefte für Zeitgeschichte” 2012, nr 2.

Wucher A., Marksteine der deutschen Zeitgeschichte 1914-1945, Darmstadt 1991.

Zieliński Z., Taktyka władz niemieckich $w$ sprawie wyktadni art. 31 konkordatu z Trzecia Rzesza w czasie od jego parafowania do ratyfikacji (8 VII-10 IX 1933 r.), „Studia nad Faszyzmem i Zbrodniami Hitlerowskimi” 22, 1999.

Zmierczak M., Pozytywizm prawniczy a prawnicy i prawo w Trzeciej Rzeszy - powojenna dyskusja niemieckich historyków i teoretyków prawa o przyczynach upadku prawa w czasach nazizmu, „Studia nad Faszyzmem i Zbrodniami Hitlerowskimi” 24, 2001.

Zmierczak M., Spory o istotę faszyzmu. Dzieje i krytyka, Poznań 1988.

\section{THE ENABLING ACT (ERMÄCHTIGUNGSGESETZ) OF 23 MARCH 1933 AS CATALYST FOR BUILDING THE FÜHRER STATE IN GERMANY}

\section{Summary}

The aim of the article is to analyze the origins and political repercussions of the Enabling Act (formally known as the "law to remedy the distress of the people and the nation") of 23 March 1933. Combined with the previously passed Reichstag Fire Decree (28 February 1933), which abolished most constitutional civil liberties and transferred state rights to the central government, the act enabled Chancellor Adolf Hitler to assume dictatorial powers in the near future. Deputies from the Nazi Party, the German National People's Party, and the Centre Party voted in favour of the act that allowed Hitler's cabinet to pass laws without the consent or any involvement of the Reichstag (parliament) and the presidency. In effect it gave Hitler's dictatorship an appearance of legality and a solid political base from which to carry out the first steps of his "national revolution" in order to seize unlimited power over every aspect of life in Germany. It was the dawn of the totalitarian regime of the Third Reich.

Keywords: Third Reich, Adolf Hitler, Nazi Party, Reichstag fire, Enabling Act.

Wojciech Wichert

wojciech.wichert@ipn.gov.pl 